\title{
Ecotoxicological characterization of biochars: role of feedstock and pyrolysis temperature
}

Domene $\mathrm{X}^{\mathrm{a}, \mathrm{b}, \mathrm{c}}$, Enders A ${ }^{\mathrm{c}}$, Hanley $\mathrm{K}^{\mathrm{c}}$, Lehmann $\mathrm{J}^{\mathrm{c}, \mathrm{d}}$.

${ }^{a}$ CREAF, Cerdanyola del Vallès, 08193, Bellaterra, Barcelona, Spain

${ }^{b}$ Universitat Autònoma de Barcelona, Cerdanyola del Vallès, 08193, Spain

${ }^{c}$ Department of Crop and Soil Sciences, Cornell University, Ithaca, NY 14853, USA

${ }^{\mathrm{d}}$ Atkinson Center for a Sustainable Future, Cornell University, Ithaca, NY 14853, USA

\section{Corresponding author:}

Xavier Domene

CREAF, Cerdanyola del Vallès, 08193, Bellaterra, Barcelona, Spain

Phone: +34 935811987

Fax: +34 935814151

e-mail: x.domene@creaf.uab.es

\section{ABSTRACT}

Seven contrasting feedstocks were subjected to slow pyrolysis at low (300 or $350^{\circ} \mathrm{C}$ ) and high temperature (550 or $600^{\circ} \mathrm{C}$ ), and both biochars and the corresponding feedstocks tested for short-term ecotoxicity using basal soil respiration and collembolan reproduction tests. After a 28-day incubation, soil basal respiration was not inhibited but stimulated by additions of feedstocks and biochars. However, variation in soil respiration was dependent on both feedstock and pyrolysis temperature. In the last case, respiration decreased with pyrolysis 
temperature $(\mathrm{r}=-0.78 ; \mathrm{p}<0.0001, \mathrm{n}=21)$ and increased with a higher volatile matter content $(\mathrm{r}=0.51 ; \mathrm{p}<0.017)$, these two variables being correlated $(\mathrm{r}=-0.86$, $\mathrm{p}<0.0001)$. Collembolan reproduction was generally unaffected by any of the additions, but when inhibited, it was mostly influenced by feedstock, and generally without any influence of charring itself and pyrolysis temperature. Strong inhibition was only observed in uncharred food waste and resulting biochars. Inhibition effects were probably linked to high soluble $\mathrm{Na}$ and $\mathrm{NH}_{4}$ concentrations when both feedstocks and biochars were considered, but mostly to soluble Na when only biochars were taken into account. The general lack of toxicity of the set of slow pyrolysis biochars in this study at typical field application rates $\left(\leqslant 20 \mathrm{Mg} \mathrm{ha}^{-1}\right)$ suggest a low short-term toxicity risk. At higher application rates (20-540 $\mathrm{Mg} \mathrm{ha}^{-1}$ ), some biochars affected collembolan reproduction to some extent, but only strongly in the food waste biochars. Such negative impacts were not anticipated by the criteria set in currently available biochar quality standards, pointing out the need to consider ecotoxicological criteria either explicitly or implicitly in biochar characterization schemes or in management recommendations.

Keywords: biochar, ecotoxicity, bioassays, microorganisms, soil basal respiration, fauna, collembolans, reproduction

\section{INTRODUCTION}

Biochar use as soil conditioner is currently an important topic of research (Gurwick et al. 2013) and related to potential benefits in the context of agricultural yield, carbon sequestration, waste management and clean energy production (Lehmann and Joseph 2009, Sohi et al 2009, Kookana et al. 2011), as well as the more recently claimed role in land reclamation (Beesley et al. 2011, Xie et al. in press). The capacity of biochar technologies to process any carbon-rich waste may allow upcycling of waste surplus or low quality wastes such as sewage or tannery sludges (Muralidhara 1982, Bridle and Pritchard 2004, Hossain et al. 2010, Méndez et al. 2013). Pyrolysis technologies have been shown to change pollutant burden of the original feedstocks, such as the usual potentially toxic element concentration 
increases due to mass losses (Koppolu et al. 2003, Méndez et al. 2012, Farrell et al. 2013) and the formation of PAH or dioxins (Schimmelpfennig and Glaser 2012, Hale et al. 2012). More recently, toxic effects of volatile organic compounds (VOCs) resulting from the re-condensation of pyrolysis liquids and gases on biochar have been demonstrated (Buss and Mašek 2014). The variety of usable feedstocks and pyrolysis procedures leads to a wide range of resulting biochars in terms of pollutant composition and burden, including biochars with unsuitable properties as a soil amendment, though still useful for other environmental benefits, e.g. charcoal use, bioenergy generation and carbon sequestration without soil application.

The soil application of some biochars might unfavorably impact soil quality. Some authors suggest a need to demonstrate both the benefits of biochar to soil health and lack of detrimental effects to the environment (Verheijen et al. 2010). However, research about possible negative impacts of biochars on soil biota is rarely addressed despite the existence of large-scale field trials and sales of biochar products in the market place (Busch et al. 2013). The potential impacts on soil biota might be roughly separated into those mediated by direct negative effects such as pollutant release and excessive salinization or liming (Liesch et al. 2010, McCormack et al. 2013), but also by indirect effects, such as a decreased albedo (Genesio et al. 2012) if associated with excessive soil heating or drying.

Most products used in agriculture conform to industrial or regulatory standards to ensure they can be safely used in soil, although for biochar this would require an agreement on the main characteristics to be taken into account (Joseph et al. 2009). Several biochar quality guidelines have been recently proposed such as the IBI Biochar Standard (IBI 2013), the European Biochar Certificate (EBC, Schmidt et al. 2012) or the UK Biochar Quality Mandate (BQM, Shackley et al. 2013). In these standards, environmental risks are accounted for by the inclusion of limit values for physicochemical properties, including pollutants such as heavy metals, dioxins/furans, PAHs, PCBs or BTEX. However, the use of chemical analyses for this purpose has several limitations such as the fact that total concentrations do not necessarily relate to the bioavailable fraction or the final uptake by organisms (Van Straalen et al. 2005); that non target toxic substances might also be present and not 
assessed; and that the combined toxicity of all the chemicals present cannot be assumed to be easily predicted since additive, synergistic and antagonist effects can occur. The use of bioassays for biochar characterization overcome such limitations, since biochar effects on indicator organisms integrate any of the processes previously described. Although bioassays have also some intrinsic limitations such as a low ecological relevance, because only short-term effects for particular cultured species are assessed, they offer a genuine possibility to assess the actual effects in exposed individuals. Bioassays are increasingly used as a tool for the prospective assessment of environmental risks of substances before its marketing, release, or agricultural use (Brock 2013), and a necessary complement to the traditional chemical characterization. Bioassay-based approaches may complement physicochemical characterization for the quality assessment of biochars, similar to what has been proposed for the characterization of wastes in the EU (Moser and Römbke 2009).

Bioassays are not included in all of the currently available biochar quality standards, with the exception of the germination assay which is mandatory in the IBI standard (IBI 2013). Studies exist utilizing plants (Solaiman et al. 2011, Rogovska et al. 2011, 2012, Busch et al. 2013), soil fauna (Liesch et al. 2010, Van Zwieten et al. 2010, Busch et al. 2012, Hale et al. 2013, Marks et al. 2014), as well as aquatic organisms (Hale et al. 2013, Oleszczuk et al. 2013), but the utility of bioassays potentially used in the context of biochar ecotoxicological characterization is still to be rigorously assessed. Furthermore, while ample data exist on the influence of the feedstock and/or the pyrolysis procedure on biochar composition, recalcitrance, or nutrient retention (Novak et al. 2009, Bruun et al. 2011, Hossain et al. 2011, Singh et al. 2012, McBeath et al. 2014, Nelissen et al. 2014), their influence on ecotoxicological effects is not yet well understood.

Therefore, we investigated the effects of a diverse set of biochars on soil basal respiration and collembolan reproduction in a bioassay. The specific objectives of the study were to assess whether charring changes the ecotoxicity of organic soil amendments; how feedstock and pyrolysis temperature affects ecotoxicity; and which amendment properties relate to negative effects. 


\section{MATERIALS AND METHODS}

\subsection{Soil, feedstocks and biochars}

The soil used in this study was collected in April 2008 in the Cornell Musgrave Research Farm (Aurora, New York). The soil was continuously cropped to corn for decades under standard, regional agricultural management practices. Soil had a $42 \%$ sand, $31 \%$ silt and $27 \%$ clay, total C content of $16.2 \mathrm{~g} \mathrm{~kg}^{-1}$, total $\mathrm{N}$ of $1.6 \mathrm{~g} \mathrm{~kg}$ ${ }^{1}$, and a pH around 7 (see Rajkovich et al. 2012 for a more detailed description). Soil was collected after snowmelt and before any pesticide or fertilization was applied. After collection, soil was air-dried, homogenized, and sieved to $5 \mathrm{~mm}$. Soil was stored for two years and before the beginning of the experiment two freezingthawing cycles $\left(24 \mathrm{~h}\right.$ at $-20^{\circ} \mathrm{C}, 24 \mathrm{~h}$ at $\left.20^{\circ} \mathrm{C}\right)$ were carried out, ensuring that no fauna remained.

Bull manure with sawdust, corn stover, oak wood and pine wood were obtained from local suppliers in Wisconsin. Digested dairy manure was supplied by AA Dairy (Candor, NY, USA), obtained after the anaerobic digestion of dairy manure and removal of the liquid fraction by a screw press. Food waste was collected from Cornell University dining halls (Ithaca, NY, USA), and included discards from food preparation, unconsumed food and paper plates and napkins. White paper mill waste was obtained in Mohawk Fine Papers Inc (Cohoes, NY, USA). The materials were dried at $60^{\circ} \mathrm{C}$ until constant weight and processed to pass a 2-mm sieve.

Two biochars were obtained from each feedstock (Table 1), obtained by slow pyrolysis at Best Energies (Cashton, WI, USA), and produced at low (300 or $350^{\circ} \mathrm{C}$ ) and high temperature $\left(550\right.$ or $600^{\circ} \mathrm{C}$ ). A detailed description of the pyrolysis procedure is provided in Enders et al. (2012). The set of biochars in this study was considered as representative, since slow pyrolysis is the most common technology to produce biochar due to its moderate operating conditions and optimization of biochar yields (Xie et al. in press).

\subsection{Biochar characterization}


Biochar and feedstock compositions are summarized in Table 2. Values for the proximate analysis, total carbon and nitrogen, and elemental composition were obtained from Enders et al. (2012), and when not available, obtained by the same methodology. Analyses were carried out in air-dried samples, ground with a mortar and pestle, and sieved to a particle size of 149-850 $\mu \mathrm{m}$. Proximate analysis (volatile matter, ash and fixed carbon content) was carried out according to ASTM D176284 and with the modifications described in Enders et al. (2012). Total carbon and nitrogen were determined by Dumas combustion (PDZ Europa ANCA-GSL, Sercon Ltd., Cheshire, UK) after ball milling (Retsch MM 301, Retsch GmbH, Haan, Germany). Elemental composition was carried using an ICP trace analyzer emission spectrometer (ICAP 61E, Thermo Electron, Waltham, MA) on dry and ground samples after ashing for $8 \mathrm{~h}$ at $500^{\circ} \mathrm{C}$ and acid digestion, according to the modified ash-method described in Enders and Lehmann (2012). Inorganic carbon was assessed by the Bernard calcimeter method, consisting of the addition of concentrated hydrochloric acid to dry ground samples and measurement of the $\mathrm{CO}_{2}$ volume released, after calibration with pure $\mathrm{CaCO}_{3}$. Organic carbon was estimated as the difference between total carbon and inorganic carbon content. $\mathrm{pH}$ and electrical conductivity were assessed in a 1:20 (w:v) solution (1.5 g of 2 mm-sieved sample in $30 \mathrm{ml}$ of deionized water), orbitally shaken for $2 \mathrm{~h}$, then centrifuged at $1935 \mathrm{x} g$ for 5 minutes, and filtered through Whatman \#1 filter paper prior to analysis, following the recommendations of IBI (2013).

Total PAH contents available for some of the biochars were obtained from Hale et al. (2012).

\subsection{Soil mixtures preparation and characterization}

Biochars and feedstocks were mixed with soil at a rate of $0,0.2,0.5,2,7$, and $14 \%$ (w/w), equivalent to an agricultural application of 0, 7.7, 19.4, 77.4, 270.9 and 541 $\mathrm{Mg} \mathrm{ha}^{-1}$, respectively. Such estimation was carried out assuming a 0.3-m arable layer depth and the field bulk density of $1.29 \mathrm{Mg} \mathrm{m}^{3}$ reported in Güereña et al. (2013) for this soil in field plots. 
The day before the beginning of the tests, soil mixtures were moistened to $50 \%$ of the water holding capacity (WHC), providing a moist and crumbly substrate required in bioassays. WHC was previously determined for each material and concentration, since water retention capacity increase with increasing feedstock and biochar application rates. Moistening of mixtures was carried out with deionised water containing $5 \%(\mathrm{v} / \mathrm{v})$ of an inoculant solution to reintroduce the indigenous microorganisms. The inoculant was prepared from freshly collected soil in the same field plots where the soil was collected two years before, and consisted of the supernatant of a soil-water slurry (1:10), stirred for $5 \mathrm{~min}$ at $150 \mathrm{rpm}$, settled for 5 min, decanted, and centrifuged for $5 \mathrm{~min}$ at $1935 \mathrm{x}$ g.

Eight replicates were prepared for each material and test concentration (6 for the bioassays, 1 for soil basal respiration, and 1 for soil analysis), each consisting of 30 g of wet soil in a sealed 150-mL polyethylene flask. Samples for the assessment of respiration and analysis were incubated for $28 \mathrm{~d}$ under dark conditions and $20 \pm 1^{\circ} \mathrm{C}$ before being analyzed, in parallel to the collembolan reproduction test.

For the assessment of chemical properties, soil-water extracts $(1: 5 \mathrm{w} / \mathrm{v})$ were prepared by adding $20 \mathrm{~g}$ of fresh sample to $100 \mathrm{~mL}$ of deionised water, orbitally shaking for $30 \mathrm{~min}$ at $160 \mathrm{rpm}$, settling, centrifuging for $5 \mathrm{~min}$ at $3600 \mathrm{x} \mathrm{g}$, and filtering through Whatman \#1 filter paper. $\mathrm{pH}$ and electrical conductivity (EC) were immediately assessed in the extracts. After storage at $-20^{\circ} \mathrm{C}, \mathrm{Cl}^{-}, \mathrm{Br}^{-}, \mathrm{S}^{-} \mathrm{SO}_{4}{ }^{2-}, \mathrm{N}-$ $\mathrm{NO}_{2}{ }^{-}, \mathrm{N}-\mathrm{NO}_{3}{ }^{-}$were analyzed in the extracts using an ICS-2000 ion chromatograph (Dionex, Sunnyvale, CA). P-PO ${ }^{2-}$ was measured as soluble reactive phosphorus (SRP) in a flow analyzer (FS 3000, OI Analytical, College Station, TX) using the ascorbic acid and molybdate method. $\mathrm{N}_{-} \mathrm{NH}_{4}{ }^{+}$was measured by the phenate method as described in APHA-AWWA-WPCF (1985). Elemental content in the extracts (Al, As, B, Ba, Ca, Cd, Co, Cr, Cu, Fe, K, Mg, Mn, Mo, N, Na, Ni, P, Pb, S, Se, Si, $\mathrm{Sr}, \mathrm{Ti}, \mathrm{V}, \mathrm{Y}$, and Zn) was assessed by ICP-ES model $61 \mathrm{E}$ trace analyzer (Thermo Jarrell Ash Co, Franklin, MA).

\subsection{Bioassays}


A minimum test battery consisting of a soil microbial activity test and a collembolan reproduction test were considered to assess the potential impacts on soil biota of the different biochars and uncharred feedstocks in this study.

Microbial activity was assessed as the basal soil respiration (BAS) in soil-material mixtures incubated for $28 \mathrm{~d}$, and measured without disturbance of the soil-mixtures by placing each replicate in 250 -mL Mason glass jars for $24 \mathrm{~h}$ at $20 \pm 1^{\circ} \mathrm{C}$, according to the titration method described in Pell et al. (2006).

Collembolan survival and reproduction was assessed according to the ISO Guideline 11267 (ISO 1999). Ten individuals, aged 10 to 12 d, were added to each of the already described replicates, thereafter incubated for $28 \mathrm{~d}$ under dark conditions at $20 \pm 1^{\circ} \mathrm{C}$. At the start of the test and $14 \mathrm{~d}$ after, granulated yeast was added to each replicate as food source to ensure the performance of the individuals. Replicates were aerated twice a week to prevent from anaerobiosis. At the end of the test, soil was poured into a 500-mL Erlenmeyer flask, flooded with water, and stirred in order to float the individuals on the water surface. Then, a picture was taken in order to count the adults and juvenile collembolan by image treatment software.

\subsection{Statistical assessment}

The statistical analyses were conducted using R software version 2.15 (R Foundation for Statistical Computing). Each bioassay was carried out using the same batch of individuals to ensure that any change in performance was exclusively attributed to the material concentration in soil mixtures and the validity criteria for this test was checked in each case. For comparison purposes, results in each bioassay were expressed as a percentage of the mean performance in the corresponding control, since reproduction varied in the different batches of collembolans used in different tests, which is usual in this parthenogenetic species related to the slight differences in breeding conditions of the different batches (e.g. feeding status) and the interindividual variability observed in this species (Crouau and Cazes 2003). 
Pearson correlation was used to link the material's composition with mean BAS and mean collembolan reproduction in each material. Within each feedstock type, the effect of material application rate and pyrolysis temperature on collembolan reproduction was assessed by two-way ANOVA (with biochar rate and pyrolysis temperature as factors), followed by Bonferroni test to assess significant differences in these endpoints with the corresponding controls. This was not possible for BAS, since only one replicate per soil-material concentration was available.

The response variables (BAS and collembolan reproduction) as affected by the exposure to the feedstocks and/or biochars were modeled by Generalized Linear Models (GLM), including feedstock/biochar concentration and a selection of the explanatory variables measured in each soil-material mixture. Concentrations below the detection limit were assumed to be zero. Prior to model construction, variables with generalized undetectable levels, were excluded as well as those showing high colinearity (Pearson, $r \geq 0.8$ ). After that, GLM were constructed assuming a Poisson distribution ( $\mathrm{glm}$ function, stats package) or, when data overdispersion was observed, a negative binomial distribution (glm.nb function, MASS package). An initial global model including the last variables was constructed, and then variables were successively removed until the best model was achieved. In Poisson GLM, the drop1 function (stats package) was used for this purpose, until all the variables selected showed a significant contribution to the model. In the negative binomial GLM, the best model was selected after removal of more variables using the vif function of the $\mathrm{HH}$ package, removing sequentially those with highest VIF values until all the variables showed VIF values below 5, and then applying the dredge function of the MuMIn package to obtain the best model (lowest AIC), restricted to five explanatory variables at most.

A principal component analysis (PCA) was carried out to ordinate the different materials based on their effects on chemical properties in soil-material mixtures using the princomp function of the stats package. The same variables selected for the GLM analysis were used for this purpose, with the exception of the application rate and BAS. 


\section{RESULTS}

\subsection{Soil chemical properties in soil-materials mixtures}

When the PCA scores of each soil-material mixture in the two main components were plotted and grouped by feedstock or pyrolysis temperature, only unpyrolyzed food waste and its corresponding biochars appeared clearly separated from the other materials along both components, while no clear clustering patterns appeared for pyrolysis temperature (Supplementary Figure S1). By means of Pearson correlation of the individual scores of each soil-material mixture in each component and the value of each physicochemical property, the main explanatory properties in each component were obtained ( $r>0.75$ ). Hence, the position of food waste materials in the low values of the first component were indicative of relatively high EC and soluble Al, Ba, Cr, Cl, Fe, K, Na, S, Si, Ti, V, Y and Zn, while the position in the high values of the second component were associated with high levels of soluble Ca and Sr. The first and second principal components explained 33.4 and $14.9 \%$ of the observed variability, respectively.

No statistical comparison could be carried out for the chemical properties in soilmaterial mixtures because only one replicate was available, although some trends are suggested. Soil pH increased slightly with the addition of manure, corn and food waste feedstocks and derived biochars with no apparent effect of pyrolysis (Supplementary Figure S2). In contrast, $\mathrm{pH}$ remained relatively unchanged or decreased after the addition of both charred and uncharred paper mill waste, oak, and pine wood, which in turn were the materials with the lowest $\mathrm{pH}$ (Supplementary Figure S3). The highest salinity was found in food waste materials and animal manures (BM, DDM), while the lowest was observed in wood materials, in accordance with their salt contents (Supplementary Figure S3). Soil mixture salinity increased linearly with application rate of feedstocks and biochars with the exception of biochars from paper mill waste, which showed no change, and wood materials which decreased salinity (Supplementary Figure S4). Unpyrolyzed materials generally showed lower salinity than the corresponding feedstocks, especially in wood materials. Although several ions are contributing to 
salinity, it was highly and positively correlated with $\mathrm{Na}$ (Pearson, $\mathrm{r}=0.95$ ), $\mathrm{Cl}^{-}$ ( $\mathrm{r}=0.88)$, and $\mathrm{Ba}^{-}(\mathrm{r}=0.83)$ in the set of materials in this study (data not shown).

\subsection{Soil respiration}

As anticipated, unpyrolized feedstocks always showed higher BAS values than the corresponding biochars, with the only exception of digested dairy manure, with similar values. The highest BAS was observed in food waste and paper mill waste, followed by bull manure, digested dairy manure and corn stover, while oak wood and pine wood showed the lowest values (Figure 1). A trend to lower BAS was observed for the highest temperature pyrolysis biochars produced from digested dairy manure, food waste and paper mill waste, although this was not found for other feedstocks. Accordingly, mean BAS in each material was significantly and inversely correlated with pyrolysis temperature (Pearson, $\mathrm{r}=-0.78$ ), but also with total C, organic C, and fixed carbon ( $\mathrm{r}=-0.59,-0.55$ and -0.68 , respectively), and positively correlated with volatile matter $(\mathrm{r}=0.51)$. Pyrolysis temperature was in turn correlated with volatile matter $(\mathrm{r}=-0.84)$ and fixed carbon $(\mathrm{r}=0.60)$, but not with total, organic, and inorganic C contents. When only biochars were considered, mean BAS was negatively correlated with fixed carbon ( $\mathrm{r}=-0.67)$ but not with pyrolysis temperature, and positively related to ash content $(\mathrm{r}=0.62)$ and total $\mathrm{N}$ $(\mathrm{r}=0.57)$.

Modelling of soil respiration response in soil-material mixtures showed a significant negative contribution of pyrolysis temperature and a positive effect of material application rate, $\mathrm{pH}$ and soluble $\mathrm{Ca}$ (Table 3), in a model explaining 74\% of the variance. When only biochars were considered, the model explained $79 \%$ of the variance and included a significant negative association with $\mathrm{N}_{-} \mathrm{NO}_{3}{ }^{-}$and a positive association with $\mathrm{Br}^{-}$.

\subsection{Collembolan reproduction}

Regarding collembolan reproduction, most of the materials assessed did not significantly affected collembolan reproduction at any of the tested concentration 
(no inhibition in 5 of the 7 unpyrolyzed feedstocks, and in 7 of the 14 biochars). Inhibition was only observed in some of the feedstocks but only at intermediate to high field equivalent application rates (Figure 2). Namely, slight but significant inhibition was found above an application rate of 0.5\% ( 19.4 $\left.\mathrm{Mg} \mathrm{ha}^{-1}\right)$ with uncharred oak wood, and biochar made from oak wood at $550^{\circ} \mathrm{C}$, and from corn stover at $350^{\circ} \mathrm{C}$, while slight inhibition were observed only above 7\% ( 77.4 Mg $\mathrm{ha}^{-1}$ ) with biochar made from bull manure at $550^{\circ} \mathrm{C}$, or paper mill waste at $300^{\circ} \mathrm{C}$. Strong reproduction suppression was observed with uncharred food waste and biochar from food waste made at $300^{\circ} \mathrm{C}$ when applied at $7 \%$ and above. The degree of inhibition within the same feedstock did not vary whether it was pyrolyzed or not, with the only exception of food waste, with more severe toxicity in the original feedstock than the corresponding biochars. Accordingly, no correlations were found between mean reproduction and pyrolysis temperature and materials composition, with the exception of the negative correlation between reproduction and materials salinity (Pearson, $\mathrm{r}=-0.49, \mathrm{p}<0.025, \mathrm{n}=21$ ) (data not shown).

The models derived for reproduction in soil-material mixtures showed a significant and negative effect of soluble $\mathrm{Na}$ and $\mathrm{Fe}$ and a positive effect of $\mathrm{S}$, though the model had low predictability, only accounting for $39 \%$ of the variance (Table 4). When only biochars were considered, the negative effect of soluble $\mathrm{Na}$ and S was still observed, as well as a negative effect of the application rate and a positive effect of soluble $\mathrm{P}$, with $40 \%$ of the variance explained by this model.

When the juvenile number was modeled, a negative effect of soluble $\mathrm{Na}$ and $\mathrm{N}$ $\mathrm{NH}_{4}{ }^{+}$was shown, and a positive effect of pyrolysis temperature, explaining 37\% of the variance (Table 5). When only biochars were included in the model, again a negative effect of soluble $\mathrm{Na}$ was shown, as well as a positive effect of $\mathrm{N}-\mathrm{NO}_{2}{ }^{-}$, but only accounting $26 \%$ of the variance.

\section{DISCUSSION}

4.1. Potentially noxious compounds in biochars and in mixtures with soil 
None of the biochars or feedstocks exceeded the total heavy metal limit values set in the IBI, EBC and BQM guidelines for basic biochar quality (see Supplementary Table S1). However, the limit values for high-grade biochar quality in the BQM guideline was exceeded for Cr (BM550), Cu (BM550, DDM300, DDW600, OW, OW350, PW550), Ni (BM550, PPM600), and Zn (BM550, DDM600) (Supplementary Figure S5). The soluble metal contents in soil-material mixtures (Supplementary Figure S6), a fraction proposed to be closely related to metal availability (Peijnenburg et al. 1997), was generally low and in a similar range in different feedstocks, agreeing with the concentrations reported in other studies for plant, manure and biosolid biochars (Farrel et al. 2003, Kloss et al. 2012, Lucchini et al. 2014). Soluble $\mathrm{Cu}$ was below the detection limit, soluble $\mathrm{Cd}$ generally decreased in biochars compared to the original feedstocks was shown, as well as increases after pyrolysis in soluble $\mathrm{Cr}, \mathrm{Ni}, \mathrm{Pb}$ and $\mathrm{Zn}$ for some of the feedstocks. The latter contrasts with studies generally reporting decreased metal leachability after pyrolysis (Hwang et al. 2007, Méndez et al 2012, Farrel et al. 2013),although explaining this result is out of the scope of the paper. Water-soluble $\mathrm{Cd}$ and $\mathrm{Zn}$ concentrations in soil-material mixtures fell clearly below those reported to inhibit reproduction of $F$. candida (4 week-reproduction EC50, expressed as soluble Cd, was $0.05-0.8 \mathrm{mg} \mathrm{Cd} \mathrm{kg}^{-1}$ and $8 \mathrm{mg}$ soluble $\mathrm{Zn} \mathrm{kg}^{-1}$ ) (Van Gestel and Hensbergen 1997, Van Gestel and Mol 2003) (Supplementary Figure S6). Similarly, soluble Pb in soil mixtures fell below the concentrations causing a reproduction inhibition in this species (0.539 $\mathrm{mg} \mathrm{Pb} \mathrm{L} \mathrm{P}^{-1}$, equivalent to around $2 \mathrm{mg}$ soluble $\mathrm{Pb} \mathrm{kg}^{-1}$ according to data and method described in Lock et al. 2006). This is consistent with the lack of correlation of soluble metals with the collembolan inhibition observed in some soil-material mixtures, and other studies that have reported no or low plant uptake of metals from biochars produced from plant materials or manures (Farrel et al. 2013, Lucchini et al. 2014) and sewage sludge (Hossain et al. 2010). However, Farrel et al. (2013) pointed out in their study that chemical extractions may be unsuitable to predict plant uptake of heavy metals from biochars.

The PAH values available for a subset of the studied biochars were clearly below the limits proposed in the already cited biochar quality standards, with the exception of the ECB limit of $4 \mu \mathrm{g} \mathrm{g}^{-1}$ for premium biochar, exceeded by paper mill 
waste biochars produced at 300 and $600^{\circ} \mathrm{C}$ and pine wood at $350^{\circ} \mathrm{C}$. Lower PAH contents are expected in slow pyrolysis biochars compared to fast pyrolysis and gasification technologies, where recondensation of biooils on biochar's surface may occur (Schimmelpfennig and Glaser 2012, Hale et al. 2012). The total concentrations of PAH in soil-biochar mixtures with those materials is not expected to cause negative effects on F. candida reproduction (Sørensen and Holmstrup 2005) and that of the closely related species F. fimetaria (Sverdrup et al. 2001) after the dilution by mixing with soil and considering the low PAH solubility and bioavailability in soils (Styrishave et al. 2008)

Apart from pollutants, excessive $\mathrm{NH}_{4}{ }^{+}$, salinization or liming after biochar application have been suggested as potential sources of biological impacts (Liesch et al. 2010). These substances are relatively transient compared to those of metals or persistent organic chemicals, but might cause immediate biological impacts shortly after the application of biochars. Ammonium levels in the materials before addition to soil was not available, but soluble contents in soil-material mixtures showed no clear trends regarding the type of feedstock, pyrolysis temperature or application rate, although a strong increase in $\mathrm{NH}_{4}{ }^{+}$levels after additions of unpyrolyzed food waste and to a lesser extent of unpyrolyzed paper mill waste was observed (data not shown).

On the other hand, the $\mathrm{pH}$ increased with pyrolysis and pyrolysis temperature $(\mathrm{r}=0.59, \mathrm{p}=0.005)$, also when only biochars were considered $(\mathrm{r}=0.59, \mathrm{p}=0.025)$ (Supplementary Figure S3), which has been associated to the ash content in a wider dataset by Enders et al. (2012). However, such increase was not associated with drastic $\mathrm{pH}$ increases in any of the soil-material mixtures (Supplementary Figure S2) probably due to the fact that the soil already had a $\mathrm{pH}$ around 7. Contradictory results have been published regarding the effect of $\mathrm{pH}$ in $\mathrm{F}$. candida, which have reported inhibition in reproduction below a pH of 5 (Sørensen and Holmstrup 2005) or above 7 (Crouau et al. 1999), while others have indicated this species to be relatively insensitive to $\mathrm{pH}$ (Domene et al 2011). Whatever the case, the limited variation in $\mathrm{pH}$ values caused by the different materials is unlikely to influence collembolans in our study. 
Strong differences in salinity were observed between feedstock types, but not with pyrolysis and pyrolysis temperature (Supplementary Figure S3), translating into salinity increases in soil mixtures. While no salinity variation was observed in soilmaterial mixtures with paper mill waste, salinity decreased in mixtures with wood feedstocks and biochars, in turn those with the lowest salt contents (Table 2). On the other hand, a high salinization effect was observed with applications of uncharred food waste and to a lower extent with applications of biochars made from food waste at 300 and $600^{\circ} \mathrm{C}$ (Supplementary Figure S4), with values close to the $2 \mathrm{dS} \mathrm{m}^{-1}$, expected to affect the yield in sensitive crops (Bernstein 1975). As already indicated, salinity was importantly explained by soluble Na concentrations, which were especially high in soil mixtures with food waste and to a lesser extent in corn stalks and manure materials (Supplementary Figure S7), known to be highly toxic (Qadir et al. 2005). In a previous study, Rajkovich et al (2012) tested the phytotoxicity of most of the biochars in our study in pot experiments, and correlated the high $\mathrm{Na}$ content in biochars with reduced growth of corn seedlings at the highest application rate tested (7\%) in biochars made from dairy manure, paper mill waste, but especially from food waste. Owojori et al. (2009) reported that juvenile production in F. candida was significantly inhibited at and above $1.03 \mathrm{dS}$ $\mathrm{m}^{-1}$ and reproduction ceased at $1.62 \mathrm{dS} \mathrm{m}^{-1}$, while survival was not affected. The latter value was exceeded with the high application rates of the most saline materials (corn stalks, manures and food waste), and may partly explain some of the observed negative effects on reproduction. Among other ions, $\mathrm{Na}^{+}$, added as $\mathrm{NaCl}$ has been shown to be more toxic than other ions applied at similar concentration (Schrader et al. 1998).

\subsection{Bioassays performance}

The PCA of the chemical properties in soil-material mixtures only separated the unpyrolyzed food waste and the derived biochars from the other materials and to a lesser extent manure materials and derived biochars (Supplementary Figure S1). This was associated with high salinity and specifically soluble Na with the addition of food waste. 


\subsubsection{Effects on BAS}

Short-term inhibition of soil respiration has been used for the ecotoxicological assessment of detrimental effects of chemicals (van Beelen and Doelman 1997, Giller et al. 1998), but also for that of wastes such as alkaline ashes (Pitchell 1990) or salinized beet vinasse (Tejada et al. 2008). Long-term effects on BAS are less relevant due to the quick selection of resistant microbial taxa able to survive in any new environment (Giller et al. 1998). Although BAS inhibition is not anticipated in most biochars, it is plausible if disruption of microorganism activity occurs. None of the feedstocks and biochars tested showed such negative effects in the shortterm, but contrarily BAS was stimulated.

Most studies have reported an initial increase in respiration shortly after the application of biochar to soil (Steinbeiss et al. 2009, Novak et al. 2010), as a result of the initial stimulation of microbial activity caused by the easily mineralizable $\mathrm{C}$ fraction present in most biochars (Lehmann et al. 2009, Kolb et al. 2009, Jones et al. 2011). Such increased activity might also be coupled with shifts in microbial communities better able to use this fraction, as shown by Jin (2010), who reported an increase in the number of taxa using simple organic compounds such as sugars or cellulose (Zygomycota), and a decrease in the groups using more complex organic carbon such as lignin (Basidiomycota and Ascomycota). This has also been supported by some studies showing increases in C-cycle soil enzymatic activities short-term after the application of biochar (Bailey et al. 2011). It has been suggested that volatile matter, measured according to ASTM standard methods, initially developed to measure the quality of coals as fuels, might correlate with biochar persistence and stimulation of respiration (Deenik 2010, Lehmann et al. 2011), which is confirmed in our study, although this relationships has not always confirmed and attributed to priming effects (Zimmerman 2010, Dempster et al. 2012).

The generalized stimulation of BAS in the materials in our study was explained by its positive correlation with volatile matter content and a negative correlation with pyrolysis temperature, and total, organic and fixed carbon. Only fixed carbon remained negatively correlated with BAS when feedstocks were excluded and only biochars were considered, which is consistent with the previous statement since 
fixed carbon is known to increase with higher pyrolysis temperature and lower volatile matter (Enders et al. 2012). Modeling of BAS in soil-material mixtures confirmed the negative contribution of pyrolysis temperature, but also a positive association with application rate, $\mathrm{pH}$ and soluble Ca levels when data from all the materials were pooled. When only biochars were considered, higher BAS was associated with lower $\mathrm{NO}_{3}{ }^{-}$levels and $\mathrm{Br}^{-}$that might be explained by an increased microbial transformation or assimilation of these compounds.

A similar effect of pyrolysis temperature on soil respiration has been reported in other studies. According to Baldock and Smernik (2002) lower mineralization would be expected for those biochars produced at higher temperatures, which in turn presented higher degree of aromatic carbon (aryl groups). In our study the effect of pyrolysis temperature on BAS is clearly mediated by its effect on volatile matter content, since both parameters are correlated in the set of materials in this study (Pearson, $\mathrm{r}=-0.86)$, and also when only biochars were considered ( $\mathrm{r}=-0.84)$.

\subsubsection{Effects on collembolan reproduction}

In our study, no strong inhibition of reproduction of the slow pyrolysis biochars and feedstocks was observed, except in the food waste materials. Furthermore, no significant effect of pyrolysis temperature on such inhibition was found, and only salinity, mostly explained by soluble $\mathrm{Na}$, was significantly correlated with the negative effects observed in the food waste feedstock and derived biochars. Only for food waste, pyrolysis was able to significantly decrease toxicity, probably due to volatile matter losses after pyrolysis and the resulting reduction of soluble $\mathrm{NH}_{4}{ }^{+}$ which is released by mineralization.

The negative effect of salinity and soluble $\mathrm{Na}$ on collembolan reproduction could be at least partly related to the interruption of egg development due to osmotic effects causing dehydration (Schrader et al. 1998). Regarding $\mathrm{NH}_{4}{ }^{+}$, it has been linked to negative impacts on soil fauna after the application of nitrogenated fertilizers (Seniczak et al. 1994) or labile organic wastes (Domene et al. 2007), but also to biochars: Liesch et al. (2010) reported that the high earthworm toxicity of a poultry litter biochar was suggested to be related by the high $\mathrm{pH}$ and gaseous $\mathrm{NH}_{3}$ 
emissions. No correlation was found in our study between toxic effect and the total metal contents in feedstocks or biochars or their soluble content in soil-material mixtures. Our results contrast with those of Marks et al. (2014), whom reported F. candida reproduction stimulation of different slow and fast pyrolysis biochars at similar application rates, as well as strong inhibition in a gasification biochar due to its high liming capacity.

\subsection{Usefulness of soil bioassays in the context of biochar characterization}

Ecological risk assessment is an increasingly used tool by environmental authorities in the United States (USEPA 1998) and the European Union (EC 2003), and defined as a process for evaluating the likelihood of adverse ecological effects occurring as a result of exposure to stressors (Gentile et al. 1993). Risk is assessed comparing the exposure concentrations with the concentrations causing biological effects (Brock 2013). Data from bioassays become the main source of biological data due to the obvious challenges of applying pollution at the field scale. Conversely, data from bioassays can be used to define safe application rates of pollutants or materials. This approach used for pollutants can also be taken for potentially polluted materials, as it has been proposed for the prospective risk assessment of wastes in the EU for the consideration of a waste as ecotoxic (Moser and Römbke 2009). The same approach could be used for the certification of biochars, ensuring its safe use in soil while preserving the wide range of environmental benefits.

The results from our study support a generalized lack of toxicity for most biochars at $0.5 \%\left(\sim 19.7 \mathrm{Mg} \mathrm{ha}^{-1}\right)$, in the range of the typical one-time biochar applications for quality soil management, mostly below $20 \mathrm{Mg} \mathrm{ha}^{-1}$ (Jeffery et al. 2011, Biederman and Harpole 2013). Similarly, in a previous study that tested all the biochars used in our study with the exception of bull manure biochars (Rajkovich et al. 2012), no phytotoxicity was observed below the $2 \%$ application. Caution needs to be exercised when application rates are maximized to sequester $C$ for climate change mitigation, and rates of individual additions be limited for those biochars that show toxicity at high applications. Furthermore, our results point out the 
suitability of soil ecotoxicological tests for the detection of problematic biochars that would not be excluded from application according to the available quality standard guidelines alone, which mostly rely on physicochemical characterization and do not include recommendations about application rates or site-specific use. Earthworm and enchytraeid avoidance tests, together with plant germination tests, have been proposed as suitable for the ecotoxicological characterization of biochars before its application in biochar trials (Major 2009). A variety of OECD and ISO standardized ecotoxicological tests exist for soil organisms that could be easily adapted for biochar testing.

\section{CONCLUSIONS}

Heavy metal content and alkalinity were characteristic for each feedstock, but generally increased after pyrolysis and with pyrolysis temperature. Alkalinity was the highest in paper mill waste, manures and corn stalk materials, and the lowest in wood materials, but in most materials increased with pyrolysis and pyrolysis temperature. On the other hand, salinity was strongly influenced by that of the original feedstock, but did not vary with pyrolysis or pyrolysis temperature. The highest salinity values were observed in food waste materials and the lowest in paper mill waste and wood materials.

Basal soil respiration was not impaired but always stimulated by feedstock or biochar application and positively correlated with volatile content of these materials. Regarding collembolans, toxicity was feedstock dependent and generally unaffected by pyrolysis or pyrolysis temperature, with strong inhibition only observed in food waste feedstock and biochars. Soluble Na was identified as the main factor responsible for inhibition in this study.

A generalized lack of toxicity was observed at concentrations in the range of usual field biochar applications rates $\left(<20 \mathrm{t} \mathrm{ha}^{-1}\right)$, indicating low short-term toxicity risk of the slow pyrolysis biochars used in this study. Bioassays were demonstrated useful for detecting potentially ecotoxicological effects of biochars, not captured by the physicochemical limit values set in different biochar quality standards currently available, which do not provide guidance for application rates specific to soil or 
crop types. This is why ecotoxicological tests are proposed as important criteria to develop management recommendations.

\section{AKCNOWLEDGEMENTS}

This study was funded by the Spanish Ministry of Science and Innovation through the CARBONET project (MICINN, CGL2010-15766). The biochar material production and field plot construction and maintenance where the test soil was obtained was funded by the United States Department of Agriculture through a Hatch grant (USDA, NY-125487), the New York State Energy Research and Development Authority (NYSERDA contract 9891), and the National Science Foundation's Basic Research for Enabling Agricultural Development (NSFBREAD, grant number IOS-0965336).

\section{FIGURE CAPTIONS}

Figure 1. 24 h-basal soil respiration in each soil-material mixtures at the end of a 28-d incubation at $21^{\circ} \mathrm{C} ; \mathrm{n}=1$.

Figure 2. Folsomia candida reproduction in the different soil-material mixtures after $28 \mathrm{~d}$. Mean values are shown and bars correspond to standard deviation. Probability values at the bottom of each graph correspond to the significance of each factor (pyrolysis temperature and biochar application rate) in a 2-way ANOVA. Asterisks within each material for a given application rate indicate significant reduction of reproduction compared to the corresponding control (Bonferroni test , $\mathrm{p}<0.05$ ); $\mathrm{n}=6$.

\section{REFERENCES}

APHA-AWWA-WPCF. 1985. Standard Methods for the Examination of Water and Wastewater (16th edition) American Public Health Association, American 
Water Works Association and Water Pollution Control Federation, Washington, DC, USA.

Bailey VL, Fansler SJ, Smith JL, Bolton Jr H. 2011. Reconciling apparent variability in effects of biochar amendment on soil enzyme activities by assay optimization. Soil Biol Biochem 43: 296-301.

Baldock JA, Smernik RJ. 2002. Chemical composition and bioavailability of thermally altered Pinus resinosa (red pine) wood. Org Geochem 33: 10931109.

Bartoń K. 2007. Model Selection and Model Averaging Based on Information Criteria (AICc and Alike): Package 'MuMIn’. http://cran.rproject.org/web/packages/MuMIn/MuMIn.pdf (accessed on 25.07.14.).

Beesley L, Moreno-Jiménez E, Gomez-Eyles J L, Harris E, Robinson B, Sizmur T. 2011. A review of biochars' potential role in the remediation, revegetation and restoration of contaminated soils. Environ Pollut 159: 3269-3282.

Bernstein L. 1975. Effects of salinity and sodicity on plant growth. Annu Rev Phytopathol 1975.13:295-312.

Biederman LA, Harpole WS. 2013. Biochar and its effects on plant productivity and nutrient cycling: a meta-analysis. GCB Bioenergy 5: 202-214.

Bridle TR, Pritchard D. 2004. Energy and nutrient recovery from sewage sludge via pyrolysis. Water Sci Technol 50: 169-175.

Brock TM. 2013. Priorities to improve the ecological risk assessment and management for pesticides in surface water. Integr Environ Assess Manag 9: $64-74$.

Bruun E W, Hauggaard-Nielsen H, Ibrahim N, Egsgaard H, Ambus P, Jensen PA, Dam-Johansen K. 2011. Influence of fast pyrolysis temperature on biochar labile fraction and short-term carbon loss in a loamy soil. Biomass Bioener 35: 1182-1189. 
Bruun EW, Ambus P, Egsgaard H, Haugaard-Nielsen H. 2012. Effects of slow and fast pyrolysis biochar on soil C and N turnover dynamics. Soil Biol Biochem 46: 73-79.

Busch D, Kammann C, Grünhage L, Müller C. 2012. Simple biotoxicity tests for evaluation of carbonaceous soil additives: establishment and reproducibility of four test procedures. J Environ Qual 41:1023-32.

Busch D, Stark A, Kammann CI, Glaser B. 2013. Genotoxic and phytotoxic risk assessment of fresh and treated hydrochar from hydrothermal carbonization compared to biochar from pyrolysis. Ecotoxicol Environ Saf 97:59-66.

Buss W, Mašek O. 2014. Mobile organic compounds in biochar: A potential source of contamination e Phytotoxic effects on cress seed (Lepidium sativum) germination. J Environ Manag 137: 111-119.

Chowdhury N, Marschner P, \& Burns R. 2011. Response of microbial activity and community structure to decreasing soil osmotic and matric potential. Plant Soil 344: 241-254.

Crouau Y, Chenon P, Gisclard C. 1999. The use of Folsomia candida (Collembola, Isotomidae) for the bioassay of xenobiotic substances and soil pollutants. App Soil Ecol 12: 103-111.

Crouau, Y, Cazes L. 2003. What causes variability in the Folsomia candida reproduction test? App Soil Ecol 22: 175-180.

Deenik JL, McClellan T, Uehara G, Antal MJ, Campbell S. 2010. Charcoal volatile matter content influences plant growth and soil nitrogen transformations. Soil Sci. Soc. Am. J. 74: 1259-1270.

Dempster DN, Gleeson DB, Solaiman ZM, Jones DL, Murphy DV. 2012. Decreased soil microbial biomass and nitrogen mineralization with Eucalyptus biochar addition to a coarse textured soil. Plant Soil 354: 311324. 
Domene X, Alcañiz JM, Andrés P. 2007. Ecotoxicological assessment of organic wastes using the soil collembolan Folsomia candida. Appl Soil Ecol 35: 461-472.

Domene X, Chelinho S, Campana P, Natal-da-Luz T, Alcañiz JM, Andrés P, Römbke J, Sousa P. 2011. Influence of soil properties on the performance of Folsomia candida: implications for its use in soil ecotoxicology testing. Environ Toxicol Chem 30: 1497-505.

Enders A, Hanley K, Whitman T, Joseph S, Lehmann J. 2012. Characterization of biochars to evaluate recalcitrance and agronomic performance. Bioresour Technol 114: 644-653.

Enders A, Lehmann J. 2012. Comparison of wet-digestion and dry-ashing methods for total elemental analysis of biochar. Commun Soil Sci Plant Anal 43:1042-1052.

EC (European Communities) 2003. Environmental Risk Assessment. Technical guidance document on risk assessment in support of commission directive 93/67/EEC on risk assessment for new notified substances, Commission Regulation (EC) No 1488/94 on Risk Assessment for existing substances, and Directive 98/8/EC of the European Parliament and of the Council concerning the placing of biocidal products on the market. Part II. European Commission-Joint Research Centre. EUR 20418 EN/2. http://echa.europa.eu/documents/10162/16960216/tgdpart2_2ed_en.pdf [accessed on 9th December 2014].

Farrell M, Rangott G, Krull E. 2013. Difficulties in using soil-based methods to assess plant availability of potentially toxic elements in biochars and their feedstocks. Journal of Hazardous Materials 250-251: 29-36.

Genesio L, Miglietta F. 2012. Surface albedo following biochar application in durum wheat. Environ Res Lett 7: 014025.

Gentile JH, Harwell MA, van der Schalie WH, Norton SB, Rodier DJ. 1993. Ecological risk assessment: A scientific perspective. J Hazard Mater 35: 241-253. 
Giller KE, Witter E, McGrath SP.1 998. Toxicity of heavy metals to microorganisms and microbial processes in agricultural soils: a review. Soil Biol Biochem 30: 1389-1414.

Güereña D, Lehmann J, Hanley K, Enders A, Hyland C, Riha S. 2013. Nitrogen dynamics following field application of biochar in a temperate North American maize-based production system. Plant Soil 365: 239-254.

Gurwick NP, Moore LA, Kelly Ch, Elias P. 2013. A systematic review of biochar research, with a focus on its stability in situ and its promise as a climate mitigation strategy. PLoS One 8.9: e75932.

Hale SE, Jensen J, Jakob L, Oleszczuk P, Hartnik T, Henriksen T, Okkenhaug G, Martinsen V, Cornelissen G. 2013. Short-term effect of the soil amendments activated carbon, biochar, and ferric oxyhydroxide on bacteria and invertebrates. Environ Sci Technol 47:8674-83.

Hale SE, Lehmann J, Rutherford D, Zimmerman AR, Bachmann RT, Shitumbanuma V, O’Toole A, Sundqvist KL, Arp HPH and Cornelissen G. 2012. Quantifying the total and bioavailable polycyclic aromatic hydrocarbons and dioxins in biochars. Environ Sci Technol 46:2830-2838.

Hilber I, Bucheli TD, Blum F, Leifeld J, Schmidt HP. 2012. Quantitative determination of PAHs in biochar - a prerequisite to assure its quality and safe application. J Agric Food Chem 60: 3042-3050.

Hossain M K, Strezov V, Chan KY, Ziolkowski A, Nelson PF. 2011. Influence of pyrolysis temperature on production and nutrient properties of wastewater sludge biochar. J Environ Manag 92: 223-228.

Hossain MK, Strezov V, Chan KY, Nelson PF. 2010. Agronomic properties of wastewater sludge biochar and bioavailability of metals in production of cherry tomato (Lycopersicon esculentum). Chemosphere 78: 1167-1171.

Hwang IH, Ouchi Y, Matsuto T. 2007. Characteristics of leachate from pyrolysis residue of sewage sludge. Chemosphere 68: 1913-1919. 
IBI (International Biochar Inititiative). 2013. Standardized Product Definition and Product Testing Guidelines for Biochar That Is Used in Soil v.1.1. http://www.biochar-international.org/characterizationstandard [accessed on 16th May 2014].

ISO (International Organization for Standardization). 1999. Soil quality - Inhibition of reproduction of Collembola (Folsomia candida) by soil pollutants. Guideline ISO 11267. Geneva, Switzerland.

Jeffery S, Verheijen FGA, Van der Velde M, Bastos AC. 2011. A quantitative review of the effects of biochar application to soils on crop productivity using meta-analysis. Agric Ecosyst Environ 144: 175-187.

Jin H. 2010. Characterization of microbial life colonizing biochar and biocharamended soils. PhD Dissertation. Cornell University, Ithaca, NY.

Jones DL, Murphy DV, Khalid M, Ahmad W, Edwards-Jones G, DeLuca TH. 2011. Short-term biochar-induced increase in soil $\mathrm{CO}_{2}$ release in both biotically and abiotically mediated. Soil Biol Biochem 43: 1723-1731.

Joseph S, Peacock C, Lehmann J, Munroe P. 2009. Developing a biochar classification and test methods. In: Lehman J, Josep h S (eds) Biochar for Environmental Management: Science and Technology. Earthscan, London, UK.

Kloss S, Zehetner F, Dellantonio A, Hamid R, Ottner F, Liedtke V, Schwanninger M, Gerzabek MH, Soja G. 2012. Characterization of slow pyrolysis biochar: effects of feedstocks and pyrolysis temperature on biochar properties. $J$ Environ Qual 41: 990-1000.

Kolb SE, Fermanich KJ, Dornbush ME. 2009. Effect of charcoal quantity on microbial biomass and activity in temperate soils. Soil Sci Soc Amer J 73: 1173-1181.

Kookana RS, Sarmah AK, Van Zwieten L, Krull E, Singh B. 2011. Biochar Application to Soil: Agronomic and Environmental Benefits and Unintended Consequences. Adv Agron 112: 103-143. 
Koppolu L, Agblevor FA, Clements LD. 2003. Pyrolysis as a technique for separating heavy metals from hyperaccumulators. Part II: Lab-scale pyrolysis of synthetic hyperaccumulator biomass. Biomass Bioenergy 25: 651-663.

Lehmann J, Joseph S. 2009. Biochar for environmental management: an introduction. In: Lehmann J, Joseph S (eds) Biochar for Environmental Management: Science and Technology. Earthscan, London, UK.

Liesch AM, Weyers SL, Gaskin JW, Das KC. 2010. Impact of two different biochars on earthworm growth and survival. AES 4: 1-9.

Liu G, Niu Z, Niekerk DV, Xue J, Zheng L. 2008. Polyciclic aromatic hydrocarbons (PAHs) from coal combustion: emissions, analysis and toxicology. Rev Environ Contam Toxicol 192: 1-28.

Lock K, Waegeneers N, Smolders E, Criel P, Van Eeckhout H, Janssen CR. 2006. Effect of leaching and aging on the bioavailability of lead to the springtail Folsomia candida. Environ Toxicol Chem 25: 2006-2010.

Lucchini P, Quilliam RS, DeLuca TH, Vamerali T, Jones DL. Does biochar application alter heavy metal dynamics in agricultural soil? Agric Ecosyst Environ 184: 149-157.

Luo Y, Durenkamp M, De Nobili M, Lin Q, Brookes PC. 2011. Short term soil priming effects and the mineralization of biochar following its incorporation to soils of different pH. Soil Biol Biochem 43: 2304-2314.

Major J. 2009. A Guide to Conducting Biochar Trials. International Biochar Initiative. http://www.biocharinternational.org/images/IBI_Biochar_Trial_Guidev1.3.pdf [accessed on 12 July 2014].

Marks EAN, Mattana S, Alcañiz JM, Domene X. 2014. Biochars provoke diverse soil mesofauna reproductive responses in laboratory bioassays. Eur J Soil Biol 60:104-111. 
McBeath AV, Smernik RJ, Krull ES, Lehmann J.2014. The influence of feedstock and production temperature on biochar carbon chemistry: A solid-state ${ }^{13} \mathrm{C}$ NMR study. Biomass Bioenergy 60: 121-129.

McCormack S, Ostle N, Bardgett RD, Hopkin DW, VanBergen AJ. 2013. Biochar in bioenergy cropping systems: impacts on soil faunal communities and linked ecosystem processes. GCB Bioenergy 5: 81-95.

Méndez A, Gómez A, Paz-Ferreiro J, Gascó G. 2012. Effects of sewage sludge biochar on plant metal availability after application to a Mediterranean soil. Chemosphere 89.11: 1354-1359.

Méndez A, Terradillos M, Gascó G. 2013. Physicochemical and agronomic properties of biochar from sewage sludge pyrolysed at different temperatures. J Anal Appl Pyrolysis. 102: 124-130.

Moser H, Römbke J. 2009. Ecotoxicological Characterization of waste: Results and experiences of an international ring test. Springer, New York, USA.

Muralidhara HS, Maggin B, Phipps H Jr. 1982. Conversion of tannery waste to useful products. Resour Conserv 8: 43-59.

Nelissen V, Ruysschaert G, Müller-Stöver D, Bodé S, Cook J, Ronsee F, Shackley S, Boeckx P, Haugaard-Nielsen H. 2014. Short-term effect of feedstock and pyrolysis temperature on biochar characteristics, soil and crop response in temperature soils. Agronomy 4: 52-73.

Novak JM, Busscher WJ, Watts DW, Laird DA, Ahmedna MA, Niandou MAS. 2010. Short-term CO2 mineralization after additions of biochar and switchgrass to a typic Kandiudult. Geoderma 154: 281-288.

Novak JM, Lima I, Xing B, Gaskin JW, Steiner C, Das KC, Ahmedna M, Rehrar D, Watts DW, Busscher WJ, Schomberg H. 2009. Characterization of designer biochar produced at different temperatures and their effects on a loamy sand. Ann Environ Sci 3: 195-206.

Oleszczuk P, Jo I, Ku M. 2013. Biochar properties regarding to contaminants content and ecotoxicological assessment. J Haz Mater 260: 375-382. 
Owojori OJ, Reinecke A J, Voua-Otomo P, Reinecke SA. 2009. Comparative study of the effects of salinity on life-cycle parameters of four soil-dwelling species (Folsomia candida, Enchytraeus doerjesi, Eisenia fetida and Aporrectodea caliginosa). Pedobiologia 52: 351-360.

Park JH, Choppala GK, Bolan N S, Chung J W, Chuasavathi T. 2011. Biochar reduces the bioavailability and phytotoxicity of heavy metals. Plant Soil 348: 439-451.

Peijnenburg WJ, Posthuma L, Eijsackers HJ, Allen HE. 1997. A conceptual framework for implementation of bioavailability of metals for environmental management purposes. Ecotoxicol Environ Saf 37:163-72.

Pell M, Stenström J, Granhall U. 2006. Soil Respiration. In: Bloem J, Hopkins DW, Benedetti A (eds) Microbiological Methods for Assessing Soil Quality. CABI Publishing. King's Lynn, UK.

Pitchel JR. 1990. Microbial respiration in fly ash/sewage-amended soils. Environ Pollut 63: 225-237.

Qadir M, Schubert S, Steffens D. 2005. Phytotoxic substances in soils. In: Hillel D (ed) Encyclopedia of Soils in the Environment. Elsevier Ltd, Oxford, UK.

Quilliam RS, Rangecroft S, Emmett BA, Deluca TH, Jones DL. 2013. Is biochar a source or sink for polycyclic aromatic hydrocarbon (PAH) compounds in agricultural soils? GCB Bioenergy. 5:96-103.

Rajkovich S, Enders A, Hanley K, Hyland C, Zimmerman AR, Lehmann, J. 2011. Corn growth and nitrogen nutrition after additions of biochars with varying properties to a temperate soil. Biol Ferti. Soils 48:271-284.

Rogovska N, Laird D, Cruse RM, Trabue S, Heaton E. 2012. Germination tests for assessing biochar quality. J Environ Qual 41:1014-22.

Schimmelpfennig S, Glaser B. 2012. One step forward toward characterization: some important material properties to distinguish biochars. J Environ Qual 41: 1001-1013. 
Schmidt HP, Abiven S, Kammann C, Glaser B, Bucheli T, Leifeld J. 2013.

Guidelines of the European Biochar Certificate.v.4.6. http://www.europeanbiochar.org/biochar/media/doc/1364855734492.pdf [accessed on 16th May 2014].

Schrader G, Metge K, Bahadir M. 1998. Importance of salt ions in ecotoxicological tests with soil arthropods. App Soil Ecol 7: 189-193.

Seniczak S, Klimek A, Kaczmarek S. 1994. The mites (Acari) of an old Scots pine forest polluted by a nitrogen fertilizer factory at Wloclawek (Poland) II: litter/soil fauna. Zool Beiträge NF 35: 199-216.

Shackley S, Ibarrola R, Hammond J, Hopkins D. 2013. Biochar Quality Mandate. British Biochar Foundation (BRAF), UK. http://biocharbraf.files.wordpress.com/2013/06/bqm-document-v2.pdf [accessed on 9th June 2014]

Singh BP, Cowie AL, Smernik RJ. 2012. Biochar carbon stability in a clayey soil as a function of feedstock and pyrolysis temperature. Environ Sci Technol 46: $11770-11778$.

Sohi S, Lopez-Capel E, Krull E, Bol R. 2009. Biochar, climate change and soil: A review to guide future research. CSIRO Land and Water Science Report 5: 17-31.

Solaiman, ZM, Murphy, D V. and Abbott, LK. 2011. Biochars influence seed germination and early growth of seedlings. Plant Soil 353:273-287.

Sørensen TS, Holmstrup M. 2005. A comparative analysis of the toxicity of eight common soil contaminants and their effects on drought tolerance in the collembolan Folsomia candida. Ecotoxicol Environ Saf 60: 132-139.

Steinbeiss S, Gleixner G, Antonietti M. 2009. Effect of biochar amendment on soil carbon balance and soil microbial activity. Soil Biol Biochem 41: 13011310.

Styrishave B, Mortensen M, Henning Krogh P, Andersen O, Jensen J. 2008. Solidphase microextraction (SPME) as a tool to predict the bioavailability and 
toxicity of pyrene to the springtail, Folsomia candida, under various soil conditions. Environ Sci Technol 42: 1332-1336.

Sverdrup LE, Kelley AE, Krogh PH, Nielsen T, Jensen J, Scott-Fordsmand J, Stenersen. 2001. Effects of eight polycyclic aromatic compounds on the survival and reproduction of the springtail Folsomia fimetaria L. (Collembola, Isotomidae). Environ Toxicol Chem 20: 1332-1338.

Tejada M, Moreno J L, Hernandez MT, Garcia C. 2007. Application of two beet vinasse forms in soil restoration: Effects on soil properties in an arid environment in southern Spain. Agric Ecosys Environ 119: 289-298.

USEPA (U.S. Environmental Protection Agency). 1998. Guidelines for Ecological Risk Assessment. Report EPA/630/R-95/002F. Washington DC, USA. http://www.epa.gov/raf/publications/pdfs/ECOTXTBX.PDF [accessed on 9th December 2014].

Van Beelen P, Doelman P. 1997. Significance and application of microbial toxicity tests in assessing ecotoxicological risks of contaminants in soil and sediment. Chemosphere 34: 455-499.

Van Gestel CAM, Hensbergen PJ. 1997. Interaction of Cd and Zn toxicity for Folsomia candida Willem (Collembola: Isotomidae) in relation to bioavailability in soil. Environ Toxicol Chem 16: 1177-1186.

Van Straalen NM, Donker MH, Vijver MG, Van Gestel CAM. 2005.

Bioavailability of contaminants estimated from uptake rates into soil invertebrates. Environ Pollut 136: 409-417.

Van Zwieten L, Kimber S, Morris S, Chan K. 2010. Effects of biochar from slow pyrolysis of papermill waste on agronomic performance and soil fertility. Plant Soil. 327:235-246.

Verheijen FGA, Jeffery S, Bastos AC, van der Velde M, Diafas I. 2010. Biochar application to soils - A critical Scientific Review of Effects on Soil Properties, Processes and Functions. Office for the Official Publications of the European Communities, EUR 24099 EN. 
Weyers SL, Spokas KA. 2011. Impact of biochar on earthworm populations: a review. App Environ Soil Sci Article ID 541592.

Wilson K, Reed D. 2012. Implications and risks of potential dioxin presence in biochar. IBI White Paper. International Biochar Initiative. http://www.biochar-international.org/sites/default/files/IBI_White_PaperImplications_of_Potential_\%20Dioxin_in_Biochar.pdf [accessed on 25 September 2013].

Xie T, Reddy KR, Wang Ch, Yargicoglu E, Spokas K. In press. Characteristics and applications of biochar for environmental remediation: A review. Crit Rev Environ Sci Technol.

Zimmerman A, Gao B, Ahn M-Y. 2011. Positive and negative carbon mineralization priming effects among a variety of biochar amended soils. Soil Biol Biochem 43: 1169-1179. 
Table 1. Source of feedstocks, and pyrolysis procedure to obtain the corresponding biochars.

\begin{tabular}{ccc}
\hline Material & Feedstock and source & Treatment \\
\hline BM & & Feedstock \\
BM350 & Bull manure w/sawdust, WI local supplier & Slow pyrolysis, $350^{\circ} \mathrm{C}$ \\
BM550 & & Slow pyrolysis, $550^{\circ} \mathrm{C}$ \\
\hline CS & Corn stalks, WI local supplier & Feedstock \\
CS350 & Slow pyrolysis, $350^{\circ} \mathrm{C}$ \\
CS550 & & Slow pyrolysis, $550^{\circ} \mathrm{C}$ \\
\hline DDM & & Feedstock \\
DDM300 & Digested Dairy Manure Screw Pressed, AA Dairy, Candor, NY & Slow pyrolysis, $300^{\circ} \mathrm{C}$ \\
DDM600 & & Slow pyrolysis, $600^{\circ} \mathrm{C}$ \\
\hline FW & & Feedstock \\
FW300 & & Slow pyrolysis, $300^{\circ} \mathrm{C}$ \\
FW600 & Food waste, Cornell dining hall & Slow pyrolysis, $600^{\circ} \mathrm{C}$ \\
\hline OW & & Feedstock \\
OW350 & WI local supplier & Slow pyrolysis, $350^{\circ} \mathrm{C}$ \\
OW550 & & Slow pyrolysis, $550^{\circ} \mathrm{C}$ \\
\hline PMW & & Feedstock \\
PMW300 & Paper Mill Waste , Mohawk Fine Papers Inc, Cohoes, NY & Slow pyrolysis, $300^{\circ} \mathrm{C}$ \\
PMW600 & & Slow pyrolysis, $600^{\circ} \mathrm{C}$ \\
\hline PW350 & & Feedstock \\
PW350 & & Slow pyrolysis, $350^{\circ} \mathrm{C}$ \\
P W550 & Pine, WI local supplier & Slow pyrolysis, $550^{\circ} \mathrm{C}$ \\
\hline
\end{tabular}


Table 2. Composition of feedstocks and their corresponding biochars; $b d l=$ below detection limit; $n a=$ not available; $\mathrm{n}=3$.

\begin{tabular}{|c|c|c|c|c|c|c|c|c|c|c|c|c|c|c|c|c|}
\hline Material & $\begin{array}{c}\text { VM } \\
\% \\
\end{array}$ & $\begin{array}{c}\text { Ash } \\
\% \\
\end{array}$ & $\begin{array}{c}\text { FixedC } \\
\% \\
\end{array}$ & $\begin{array}{c}\text { Ctot } \\
\% \\
\end{array}$ & $\begin{array}{c}\text { Cinorg } \\
\% \\
\end{array}$ & $\begin{array}{c}\text { Corg } \\
\% \\
\end{array}$ & $\begin{array}{l}\mathbf{N} \\
\% \\
\end{array}$ & $\begin{array}{c}\text { Cd } \\
\mathrm{mg} \mathrm{kg}^{-1} \\
\end{array}$ & $\begin{array}{c}\mathbf{C r} \\
\mathrm{mg} \mathrm{kg}^{-1} \\
\end{array}$ & $\begin{array}{c}\mathbf{C u} \\
\mathrm{mg} \mathrm{kg}^{-1} \\
\end{array}$ & $\begin{array}{c}\mathbf{N i} \\
\mathrm{mg} \mathrm{kg}^{-1} \\
\end{array}$ & $\begin{array}{c}\mathbf{P b} \\
\mathrm{mg} \mathrm{kg}^{-1} \\
\end{array}$ & $\begin{array}{c}\mathbf{Z n} \\
\mathrm{mg} \mathrm{kg}^{-1} \\
\end{array}$ & $\begin{array}{r}\mathbf{p H} \\
\mathrm{mg} \mathrm{kg}^{-1} \\
\end{array}$ & $\begin{array}{c}\text { EC } \\
\mathrm{dS} \mathrm{m}^{-1} \\
\end{array}$ & $\begin{array}{c}\text { Total PAH } \\
\mu \mathrm{g} \mathrm{g}^{-1}\end{array}$ \\
\hline $\mathrm{BM}$ & 84.4 & 5.3 & 10.2 & 43.8 & bdl & 43.8 & 0.6 & bdl & 1.7 & 13.9 & bdl & bdl & 65.81 & 7.58 & 2.16 & na \\
\hline BM350 & 58.7 & 8.3 & 33 & 66.3 & 0.05 & 66.2 & 1.3 & 0.42 & 2.0 & 35.6 & 2.36 & 3.54 & 132.96 & 7.51 & 2.18 & na \\
\hline BM550 & 39 & 10.9 & 50.1 & 74.3 & 0.11 & 74.2 & 1.1 & 0.08 & 18.6 & 44.2 & 14.01 & 2.47 & 319.53 & 10.57 & 2.77 & na \\
\hline CS & 85.2 & 9.0 & 5.8 & 43.4 & bdl & 43.4 & 0.5 & bdl & 1.7 & 6.4 & bdl & bdl & 59.42 & 5.69 & 1.19 & na \\
\hline CS350 & 48.9 & 11.5 & 39.8 & 65.2 & 0.03 & 65.2 & 1.2 & bdl & 2.2 & 21.5 & 0.98 & 1.71 & 66.03 & 7.81 & 1.73 & 1.61 \\
\hline CS550 & 37.3 & 14 & 48.7 & 72.2 & 0.06 & 72.1 & 1.00 & 0.16 & 2.5 & 30.5 & 2.18 & 4.31 & 87.81 & 10.02 & 1.29 & 1.76 \\
\hline DDM & 74.7 & 6.92 & 18.4 & 45 & 0.01 & 50.0 & 1.7 & bdl & 1.3 & 12.6 & 0.70 & 0.48 & 36.45 & 7.91 & 1.44 & na \\
\hline DDM300 & 57.6 & 39.2 & 3.2 & 56.1 & 0.05 & 56.0 & 2.7 & bdl & 2.3 & 47.5 & 5.75 & 24.27 & 129.24 & 8.20 & 1.87 & 0.33 \\
\hline DDM600 & 39.4 & 18.8 & 41.7 & 62.8 & 0.04 & 62.8 & 2.2 & bdl & 3.1 & 58.3 & 3.86 & bdl & 200.19 & 10.37 & 1.65 & 0.18 \\
\hline FW & 51.1 & 39.2 & 9.68 & 42.6 & 0.51 & 42.1 & 2.4 & bdl & 2.4 & 4.3 & 2.83 & 1.91 & 20.70 & 5.40 & 3.81 & na \\
\hline FW300 & 45.4 & 23.3 & 31.3 & 65.3 & 0.12 & 65.2 & 5.3 & bdl & 6.3 & 41.9 & 6.40 & 41.15 & 49.41 & 7.50 & 4.37 & 0.37 \\
\hline FW600 & 34.5 & 52 & 13.6 & 32 & 1.09 & 30.9 & 1.2 & bdl & 8.7 & 10.9 & 9.82 & bdl & 64.17 & 10.10 & 4.28 & 0.09 \\
\hline OW & 88.6 & 2 & 9.4 & 47.1 & bdl & 47.1 & 0.1 & bdl & 0.6 & 106.4 & bdl & bdl & 47.37 & 3.98 & 0.10 & na \\
\hline OW350 & 60.8 & 1.1 & 38.1 & 74.9 & bdl & 74.9 & 0.2 & 0.55 & 14.5 & 120.1 & 9.10 & 20.66 & 109.05 & 4.49 & 0.06 & na \\
\hline OW550 & 38.5 & 0.6 & 60.9 & 87.9 & bdl & 87.9 & 0.2 & 0.11 & 0.9 & 25.8 & 1.23 & 5.47 & 15.10 & 7.42 & 0.03 & na \\
\hline PMW & 60 & 38.2 & 1.74 & 23.5 & 5.4 & 18.1 & 0.1 & bdl & 3.0 & 4.2 & 1.72 & 2.58 & 7.07 & 8.05 & 0.19 & na \\
\hline PMW300 & 50.1 & 50.7 & -0.8 & 21.2 & 6.23 & 15.0 & 0.3 & bdl & 8.2 & 17.8 & 7.09 & 1.62 & 25.71 & 7.58 & 0.45 & 0.18 \\
\hline PMW600 & 41.1 & 59.1 & -0.2 & 19.2 & 8.14 & 11.1 & 0.1 & 0.002 & 11.0 & 21.2 & 11.27 & 13.92 & 50.52 & 9.28 & 0.18 & 0.27 \\
\hline PW & 89.8 & 1.8 & 8.3 & 47 & bdl & 47.0 & 0.00 & 1.40 & 1.7 & 131.2 & 1.37 & 11.80 & 45.60 & 4.53 & 0.19 & na \\
\hline PW350 & 56.3 & 0.6 & 43.2 & 70.7 & bdl & 70.7 & 0.1 & 1.40 & 0.6 & 13.5 & 1.25 & 8.50 & 20.99 & 4.72 & 0.07 & na \\
\hline PW550 & 40.2 & 0.8 & 59 & 86.8 & bdl & 86.8 & 0.1 & 0.17 & 4.3 & 65.3 & 0.84 & 36.48 & 37.57 & 6.23 & 0.02 & na \\
\hline
\end{tabular}


Table 3. GLM models for basal respiration assuming Poisson distribution and combining feedstocks and biochars (left) or only considering biochars (right).

\begin{tabular}{lcccc}
\hline & Estimate & Std. Error & z value & $\operatorname{Pr}(>|\mathbf{z}|)$ \\
\hline Intercept & -4.7626 & 1.75348 & -2.716 & 0.00661 \\
Application rate & 0.09346 & 0.0143576 & 6.5107 & $<0.0001$ \\
Pyrolysis temperature & -0.0021 & 0.0003511 & -6.0621 & $<0.0001$ \\
pH & 0.67479 & 0.250924 & 2.689 & 0.00716 \\
Ca & 0.00455 & 0.0019166 & 2.372 & 0.01771 \\
\hline
\end{tabular}

Null deviance: 143.471 on 125 degrees of freedom

Residual deviance: 36.705 on 121 degrees of freedom

$\mathbf{R}^{2}: 0.74$

\begin{tabular}{lcccc}
\hline & & & & \\
& Estimate & Std. Error & z value & $\operatorname{Pr}(>|\mathbf{z}|)$ \\
\hline Intercept & -0.096 & 0.328715 & -0.292 & 0.7701 \\
Br $^{-}$ & 0.0342 & 0.007857 & 4.362 & $<0.001$ \\
$\mathbf{N}^{-N O}{ }_{3}^{-}$ & -0.0108 & 0.004732 & -2.279 & 0.0227 \\
\hline
\end{tabular}

Null deviance: 43.508 on 83 degrees of freedom Residual deviance: 9.156 on 81 degrees of freedom $\mathbf{R}^{2}: 0.79$ 
Table 4. GLM models for collembolan reproduction (expressed as \%) assuming Poisson distribution and combining feedstocks and biochars (left) or only considering biochars (right).

\begin{tabular}{|c|c|c|c|c|}
\hline & Estimate & $\begin{array}{c}\text { Std. } \\
\text { Error }\end{array}$ & $\mathrm{z}$ value & $\operatorname{Pr}(>|\mathbf{z}|)$ \\
\hline Intercept & 4.5289 & 0.0442 & 102.468 & $<0.0001$ \\
\hline $\mathbf{F e}$ & -0.0128 & 0.0036 & -3.526 & 0.0004 \\
\hline $\mathbf{N a}$ & -0.0024 & 0.0003 & -8.701 & $<0.0001$ \\
\hline S & 0.0114 & 0.0034 & 3.376 & 0.0007 \\
\hline
\end{tabular}

Null deviance: 285.91 on 125 degrees of freedom Residual deviance: 173.18 on 122 degrees of freedom $\mathbf{R}^{2}: 0.39$

\begin{tabular}{lcccc}
\hline & \multicolumn{3}{c}{ Std. } & \\
& Estimate & Error & z value & $\operatorname{Pr}(>|\mathbf{z}|)$ \\
\hline Intercept & 4.691 & 0.04007 & 117.08 & $<0.001$ \\
Application rate & -0.0137 & 0.00527 & -2.594 & 0.0095 \\
P-PO4 $^{2-}$ & 0.01735 & 0.00476 & 3.645 & 0.00027 \\
Fe & -0.0077 & 0.00377 & -2.053 & 0.0401 \\
Na & -0.0019 & 0.00028 & -6.751 & $<0.001$ \\
\hline
\end{tabular}

Null deviance: 205.83 on 83 degrees of freedom Residual deviance: 121.48 on 79 degrees of freedom $\mathbf{R}^{2}: 0.409$ 
Table 5. GLM models for reproduction (juvenile number) assuming negative binomial distribution and combining feedstocks and biochars (left) or only considering biochars (right).

\begin{tabular}{lcccc}
\hline & \multicolumn{3}{c}{ Std. } & \\
& Estimate & Error & z value & $\operatorname{Pr}(>|\mathbf{z}|)$ \\
\hline Intercept & 6.8746 & 0.0487983 & 140.878 & $<0.001$ \\
Temperature & 0.00043 & 0.0001221 & 3.512 & 0.00045 \\
$\mathbf{N}^{+} \mathbf{N H}_{\mathbf{4}}^{+}$ & -0.13 & 0.0261146 & -4.977 & $<0.001$ \\
$\mathbf{N a}$ & -0.0023 & 0.000329 & -6.942 & $<0.001$ \\
\hline
\end{tabular}

Null deviance: 215.48 on 125 degrees of freedom Residual deviance: 134.27 on 122 degrees of freedom $\mathbf{R}^{2}: 0.37$

\begin{tabular}{|c|c|c|c|c|}
\hline & Estimate & $\begin{array}{c}\text { Std. } \\
\text { Error }\end{array}$ & z value & $\operatorname{Pr}(>|z|)$ \\
\hline Inte & 6.92744 & 0.0543107 & 127.552 & $<0.001$ \\
\hline $\mathrm{N}-\mathrm{NO}_{2}^{-}$ & 0.09709 & 0.0356535 & 2.723 & 0.00647 \\
\hline $\mathrm{Na}$ & -0.0022 & 0.0003644 & -5.905 & $<0.001$ \\
\hline
\end{tabular}

Null deviance: 121.603 on 83 degrees of freedom Residual deviance: 89.885 on 81 degrees of freedom $\mathbf{R}^{2}: 0.26$ 
Bull manure

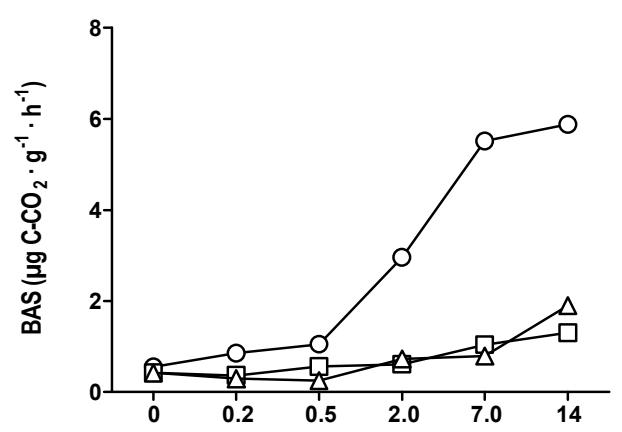

Dairy manure

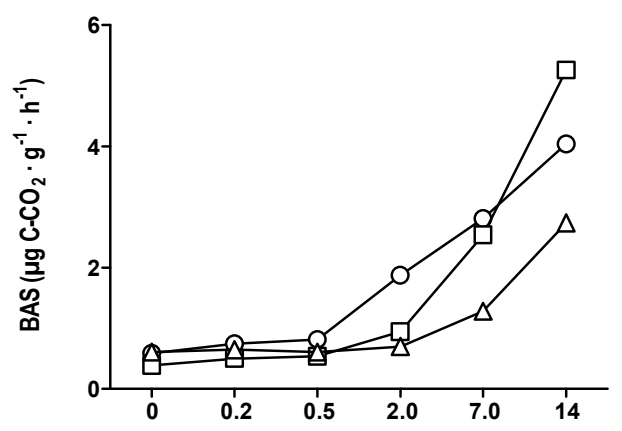

Oak wood
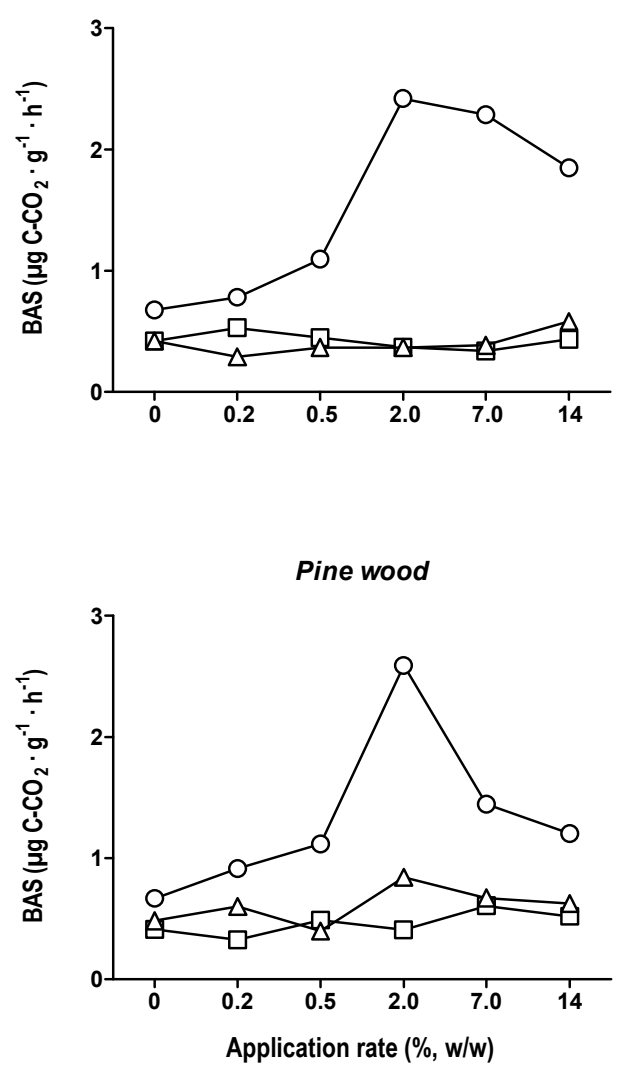

Corn stalks

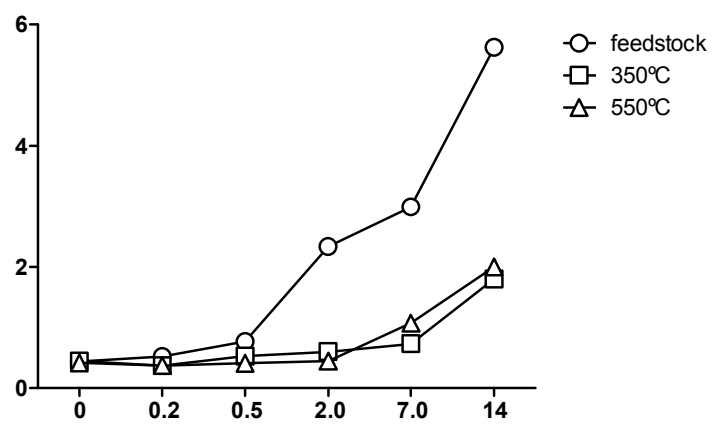

Food waste

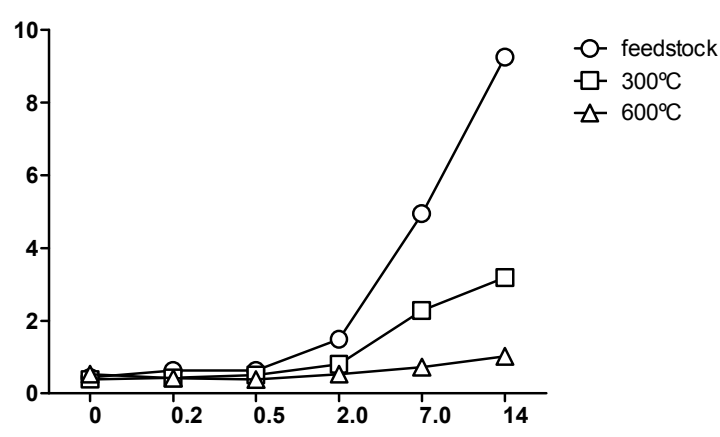

Paper mill waste

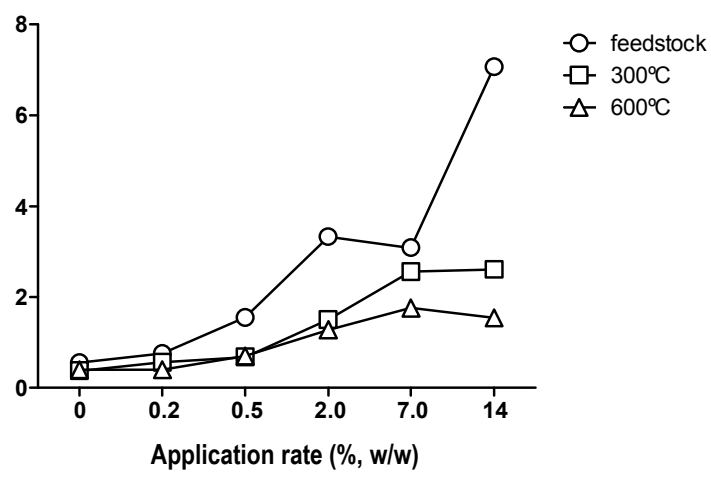

-O- feedstock

ㅁ $350^{\circ} \mathrm{C}$

$\triangle 550^{\circ} \mathrm{C}$ 
Bull manure

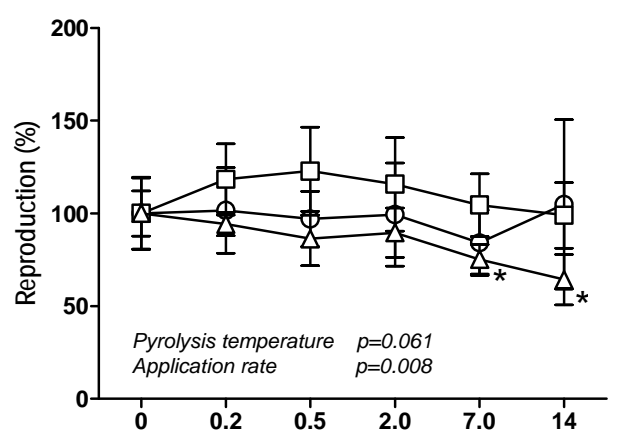

Dairy manure

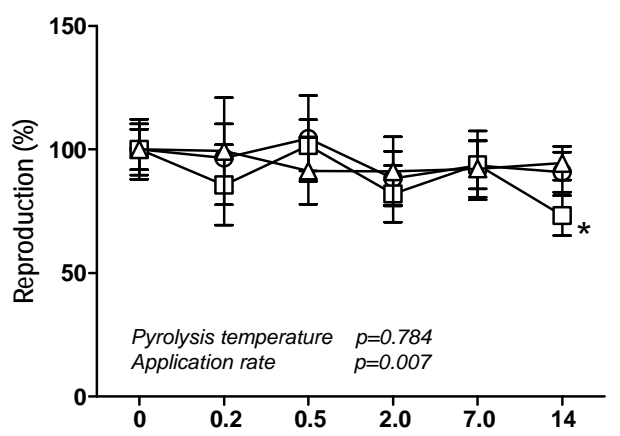

Oak wood

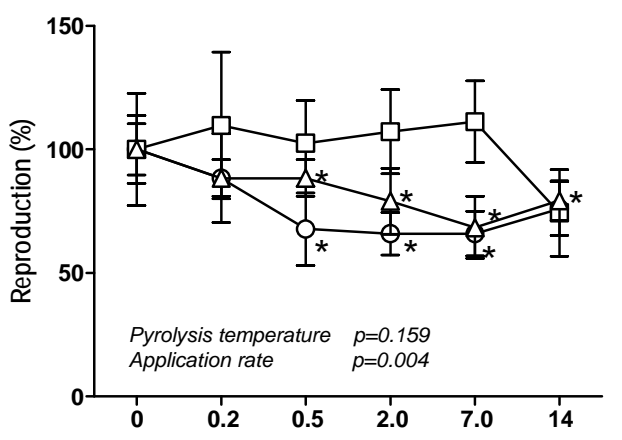

Pine wood

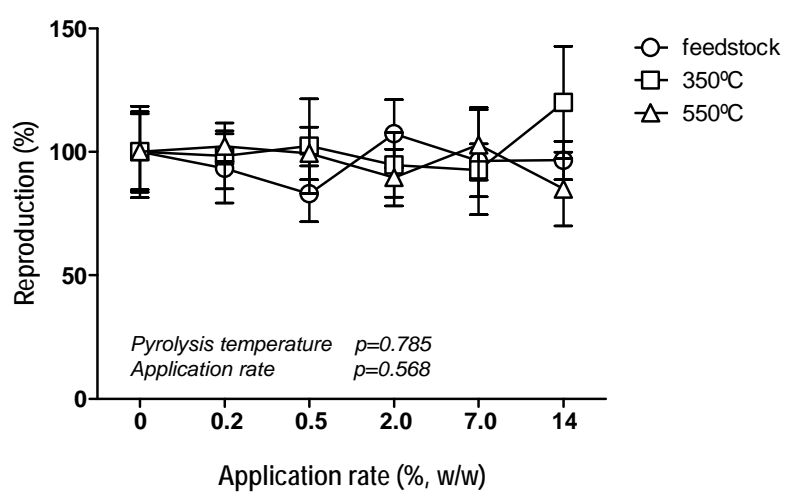

Corn stalks

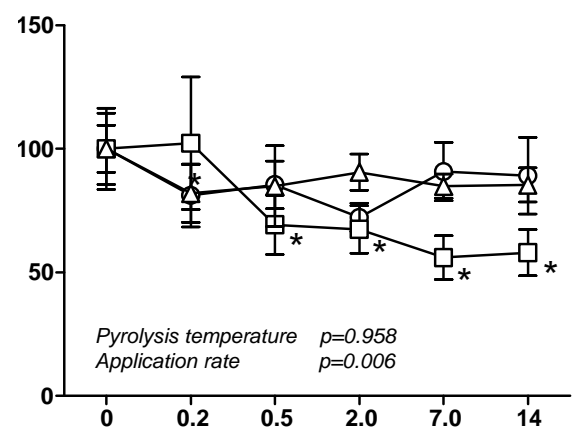

- O- feedstock

마 $350^{\circ} \mathrm{C}$

$\triangle 550^{\circ} \mathrm{C}$

ㅁ. $350^{\circ} \mathrm{C}$

$\triangle 550^{\circ} \mathrm{C}$

- O- feedstock

마 $300^{\circ} \mathrm{C}$

$\triangle 600^{\circ} \mathrm{C}$

- - feedstock

ㅁ. $350^{\circ} \mathrm{C}$

$\triangle 550^{\circ} \mathrm{C}$

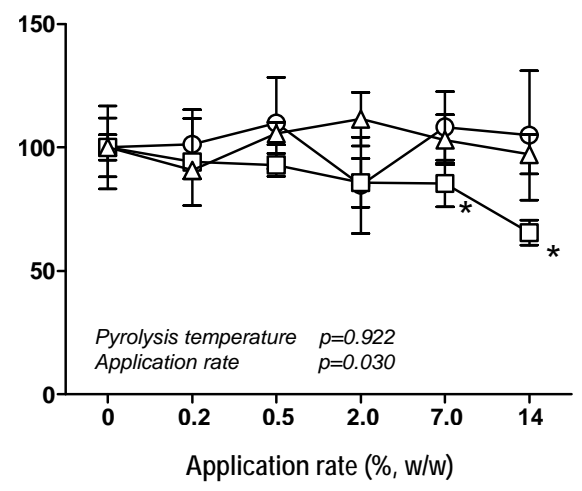

-O- feedstock

마 $300^{\circ} \mathrm{C}$

$\triangle-600^{\circ} \mathrm{C}$

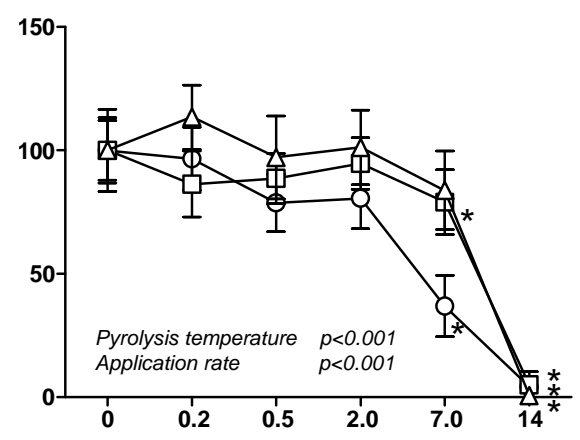

-o- feedstock

마 $300^{\circ} \mathrm{C}$

$\triangle 600^{\circ} \mathrm{C}$ 
Supplementary Table S2. Limit values for pollutant burden in biocha

\begin{tabular}{|c|c|c|c|}
\hline Pollutant & Unit & IBI (2013) ${ }^{1}$ & basic grade $^{\text {Scl }}$ \\
\hline As & $\mathrm{mg} \mathrm{kg}^{-1}$ & 12 to 100 & n.a. \\
\hline Cd & $\mathrm{mg} \mathrm{kg}^{-1}$ & 1.4 to 39 & 1,5 \\
\hline Cr & $\mathrm{mg} \mathrm{kg}^{-1}$ & 64 to 1200 & 90 \\
\hline Co & $\mathrm{mg} \mathrm{kg}^{-1}$ & 40 to 150 & n.a. \\
\hline $\mathrm{Cu}$ & $\mathrm{mg} \mathrm{kg}^{-1}$ & 63 to 1500 & 100 \\
\hline $\mathbf{P b}$ & $\mathrm{mg} \mathrm{kg}^{-1}$ & 70 to 500 & 150 \\
\hline Hg & $\mathrm{mg} \mathrm{kg}^{-1}$ & 1 to 17 & 1 \\
\hline Mn & $\mathrm{mg} \mathrm{kg}^{-1}$ & n.a. & n.a. \\
\hline Mo & $\mathrm{mg} \mathrm{kg}^{-1}$ & 5 to 20 & n.a. \\
\hline $\mathbf{N i}$ & $\mathrm{mg} \mathrm{kg}^{-1}$ & 47 to 600 & 50 \\
\hline Se & $\mathrm{mg} \mathrm{kg}^{-1}$ & 1 to 36 & n.a. \\
\hline Zn & $\mathrm{mg} \mathrm{kg}^{-1}$ & 200 to 7000 & 400 \\
\hline Bo & $\mathrm{mg} \mathrm{kg}^{-1}$ & only declaration & n.a. \\
\hline Cl & $\mathrm{mg} \mathrm{kg}^{-1}$ & only declaration & n.a. \\
\hline $\mathbf{N a}$ & $\mathrm{mg} \mathrm{kg}^{-1}$ & only declaration & n.a. \\
\hline PAHs & $\mathrm{mg} \mathrm{kg}^{-1}$ & 6 to 20 & 12 \\
\hline BETX & & n.a. & n.a. \\
\hline PCDDs/Fs & ng kg ${ }^{-1}$ & 9 (ng kg$\left.{ }^{-1} \mathrm{TEQ}\right)$ & 20 \\
\hline PCBs & $\mathrm{mg} \mathrm{kg}^{-1} \mathrm{TEQ}$ & 0.2 to 0.5 & 0.2 \\
\hline pH & & only declaration & n.a. \\
\hline EC & $\mathrm{dS} \mathrm{m}^{-1}$ & only declaration & n.a. \\
\hline
\end{tabular}

${ }^{1}$ IBI range of maximum allowed threshold for test category B (biocha ${ }^{2}$ EBC maximum limit suggested for standard and high grade quality $b$ ${ }^{3} B Q M$ threshold for basic and premium quality grade 
Irs in different guidelines of biochar quality assessment.

\begin{tabular}{|c|c|c|}
\hline \multirow{2}{*}{$\begin{array}{r}\text { imidt et al. }(2013)^{2} \\
\text { premium grade }\end{array}$} & \multicolumn{2}{|c|}{ Shackley et al. (2013) ${ }^{3}$} \\
\hline & standard grade & high grade \\
\hline n.a. & 100 & 10 \\
\hline 1 & 39 & 3 \\
\hline 80 & 100 & 15 \\
\hline n.a. & n.a. & n.a. \\
\hline 100 & 1500 & 40 \\
\hline 120 & 500 & 60 \\
\hline 1 & 17 & 1 \\
\hline n.a. & n.a. & 3500 \\
\hline n.a. & 75 & 10 \\
\hline 30 & 600 & 10 \\
\hline n.a. & 100 & 5 \\
\hline 400 & 2800 & 150 \\
\hline n.a. & n.a. & n.a. \\
\hline n.a. & n.a. & n.a. \\
\hline n.a. & n.a. & n.a. \\
\hline 4 & 20 & 20 \\
\hline n.a. & to be confirmed & to be confirmed \\
\hline 20 & 20 & 20 \\
\hline 0.2 & 0.5 & 0.5 \\
\hline handling information if $\mathrm{pH}>10$ & only declaration & only declaration \\
\hline n.a. & optional & optional \\
\hline
\end{tabular}

r must be below the highest value of the range)

iochar 

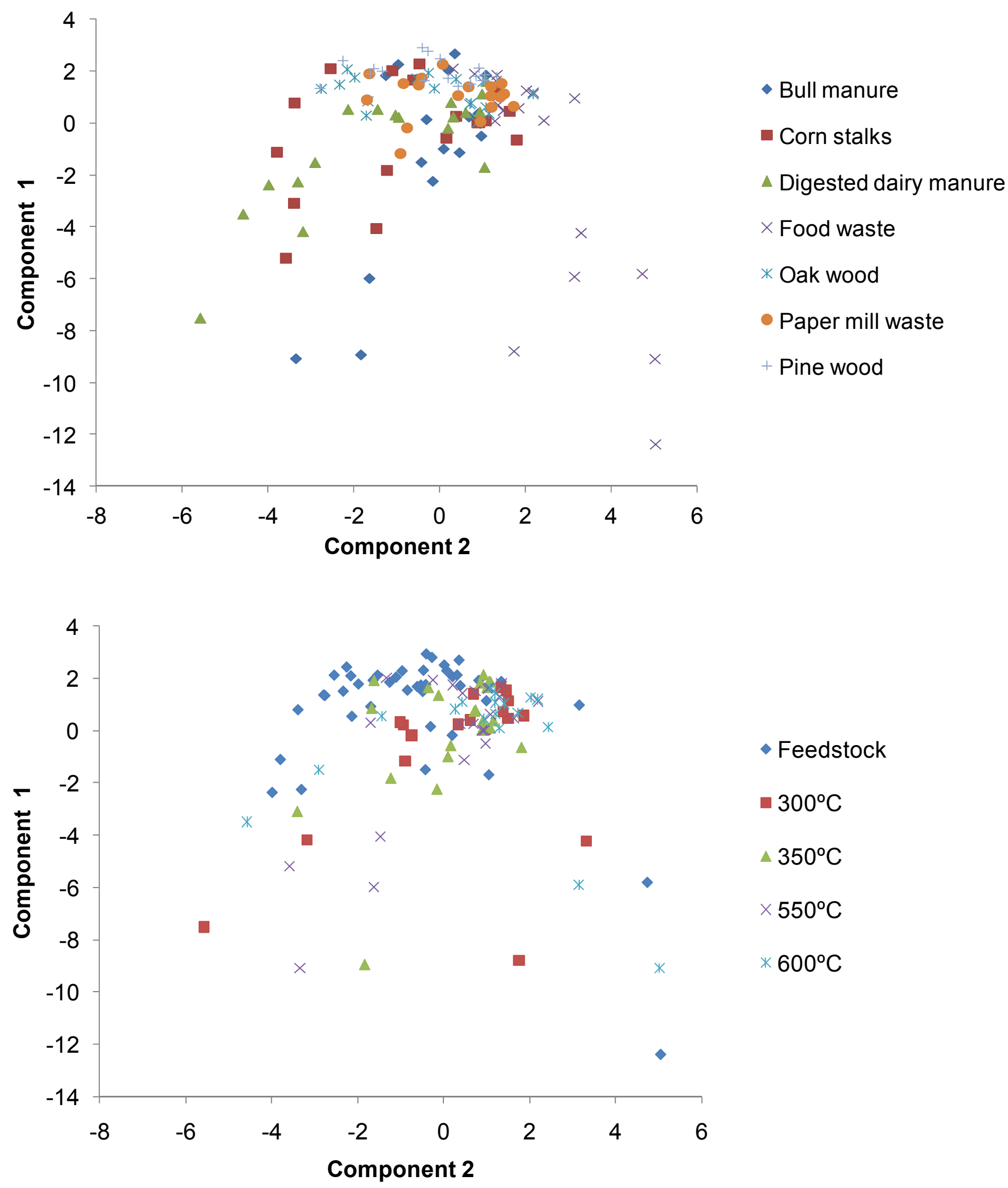

Supplementary Figure S1. Scatterplot of the principal component analysis of the soil physicochemical properties measured in the different soil-material mixtures, grouped by feedstock (upper graphic) and pyrolysis temperature (lower graphic). The first component explained $33.4 \%$ of the variance while the second explained $14.9 \%$ of the variance. 
Bull manure

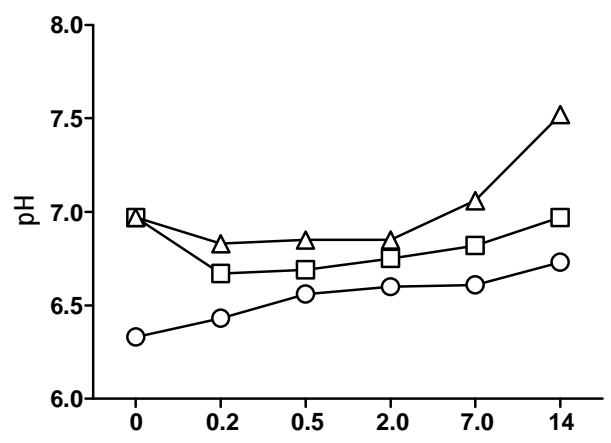

Dairy manure

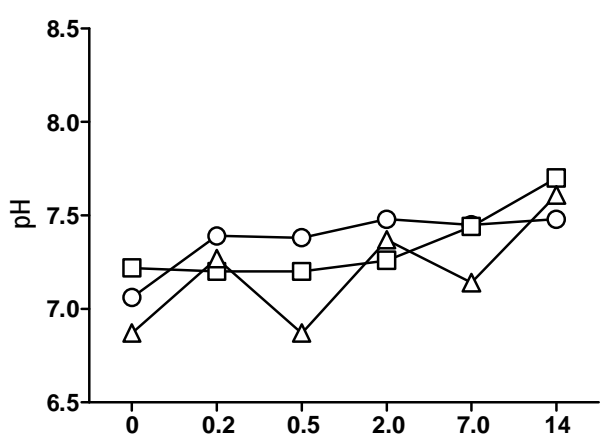

Oak wood

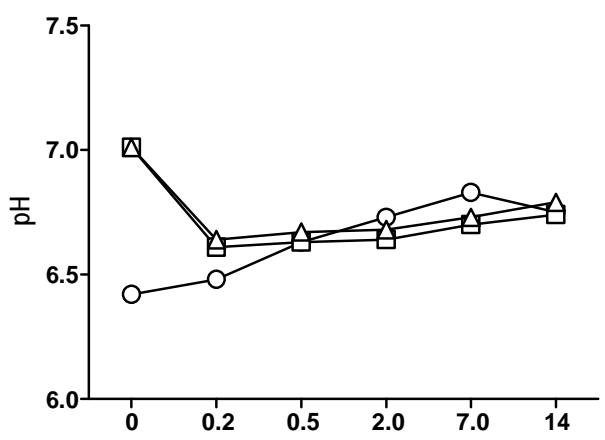

Pine wood

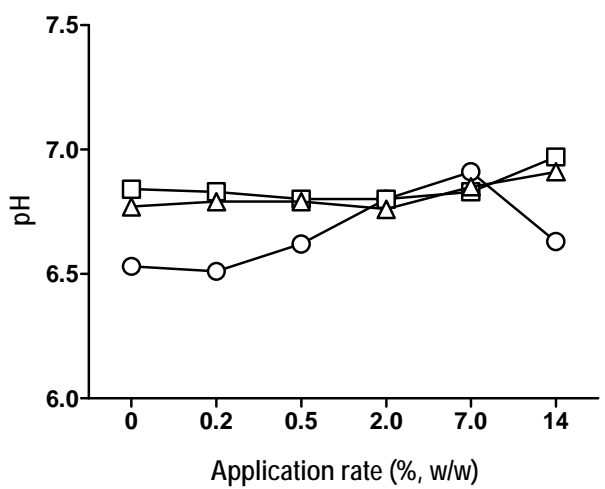

Corn stalks

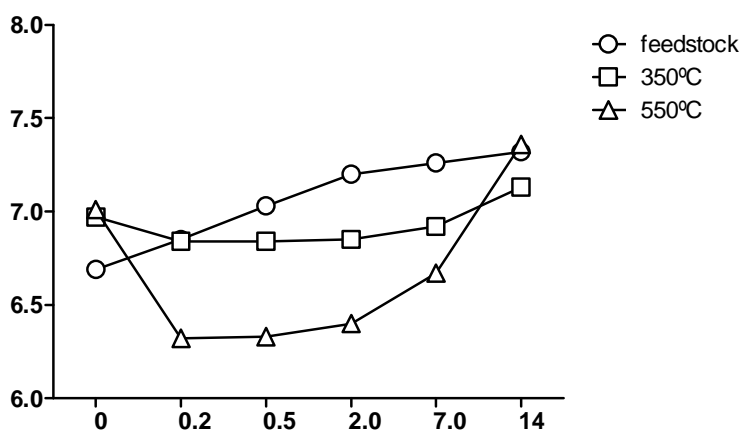

Food waste
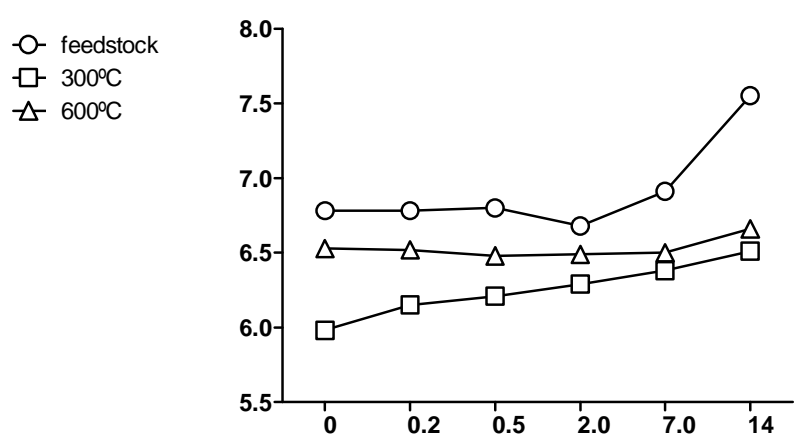

- - feedstock

ㅁ $300^{\circ} \mathrm{C}$

$-\triangle 600^{\circ} \mathrm{C}$

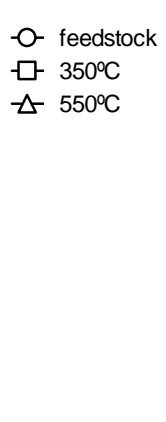

-o- feedstock

ㅁ. $350^{\circ} \mathrm{C}$

$\triangle 550^{\circ} \mathrm{C}$

Paper mill waste

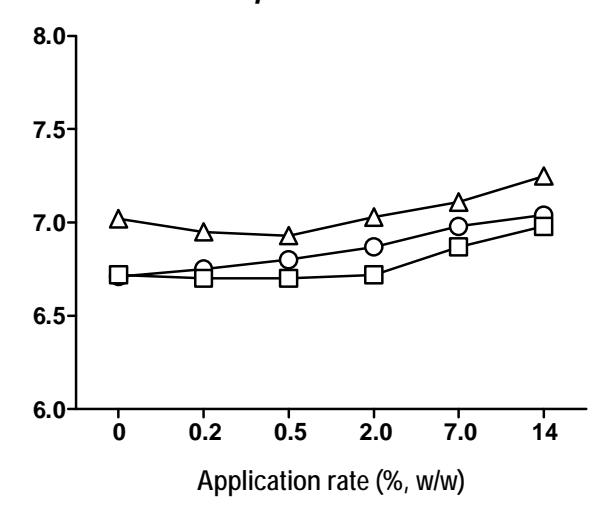

- - feedstock

$-7300^{\circ} \mathrm{C}$

$\triangle 600^{\circ} \mathrm{C}$

Application rate (\%, w/w)

Supplementary Figure S2. $\mathrm{pH}$ in the different soil-material mixtures at increasing application rates; $n=2$. 

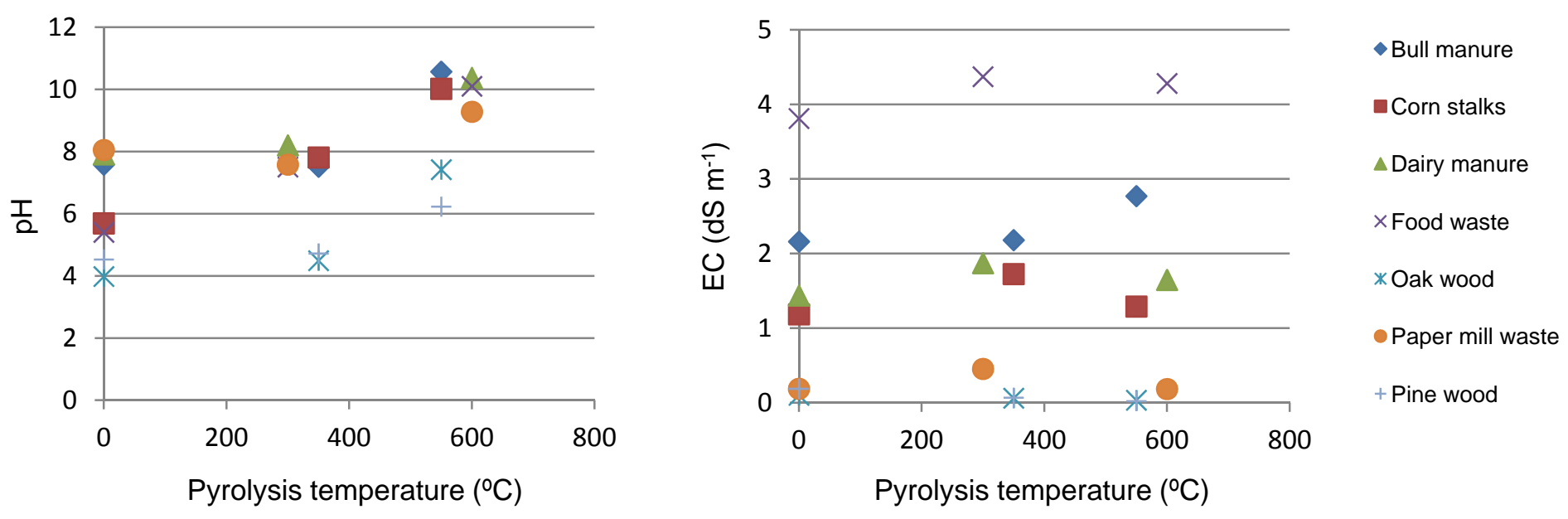

Supplementary Figure S3. $\mathrm{pH}$ and electrical conductivity in a 1:20 (w:v) solution for the different feedstocks and biochars. Data for unpyrolyzed feedstocks correspond to a pyrolysis temperature of zero; $n=2$. 

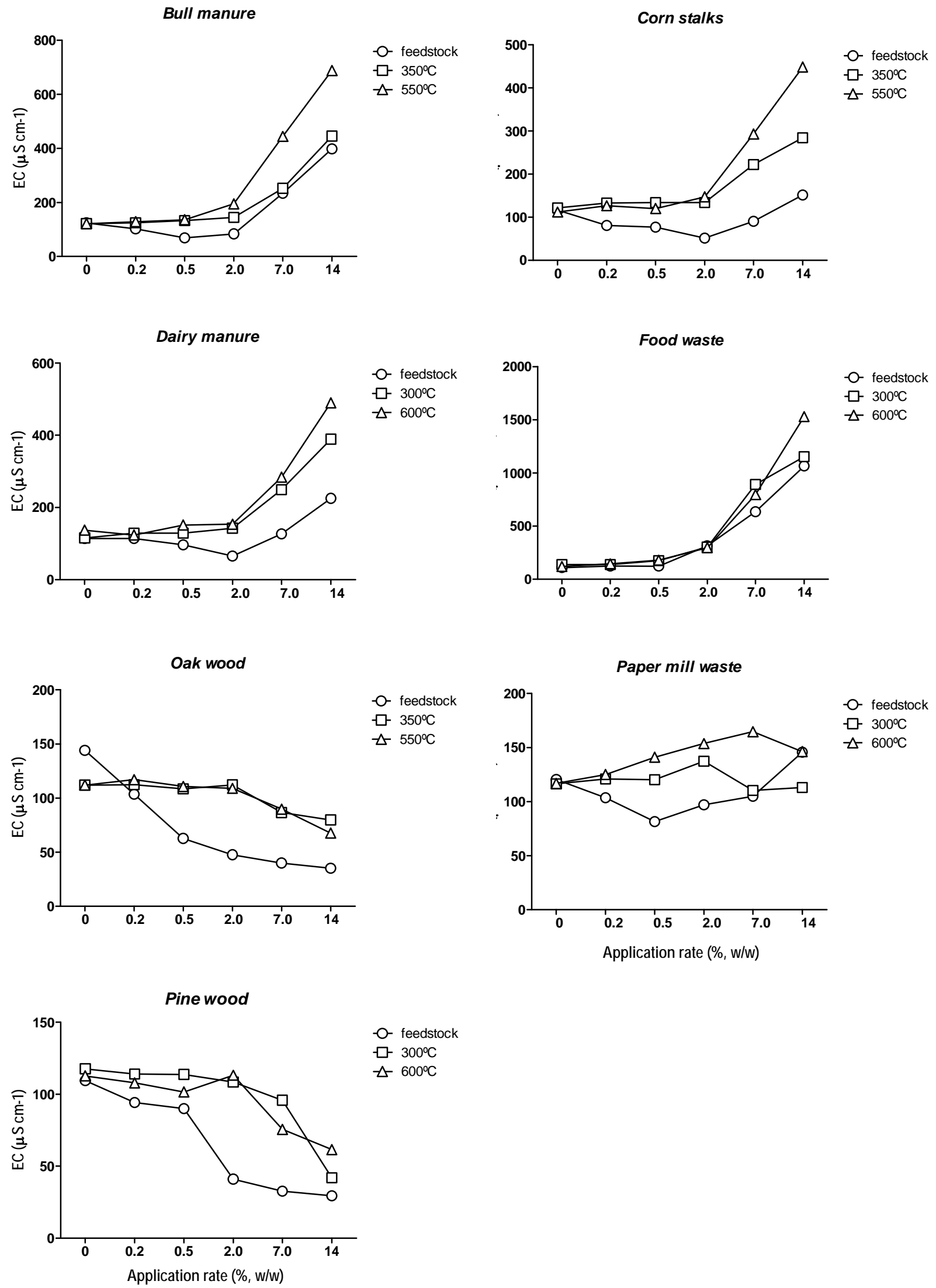

Supplementary Figure S4. Electrical conductivity in the different soil-material mixtures at increasing application rates; $n=2$. 

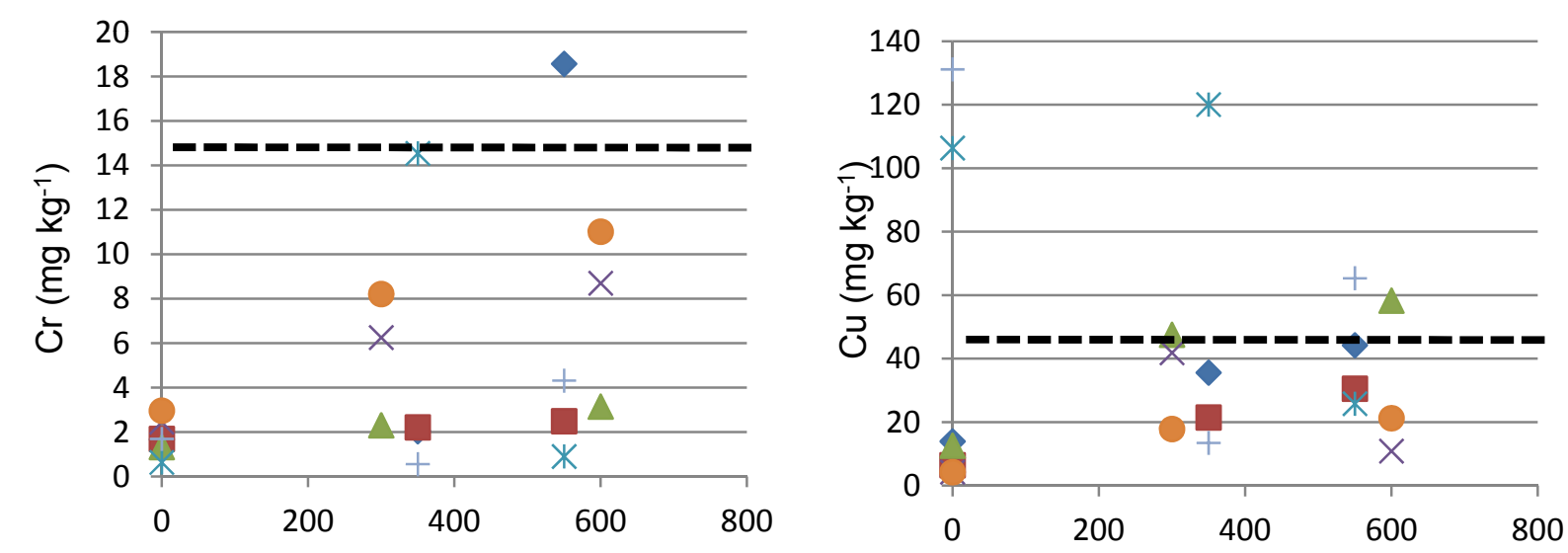

Bull manure

Corn stalks

$\triangle$ Dairy manure

$\times$ Food waste

* Oak wood

Paper mill waste

+ Pine wood
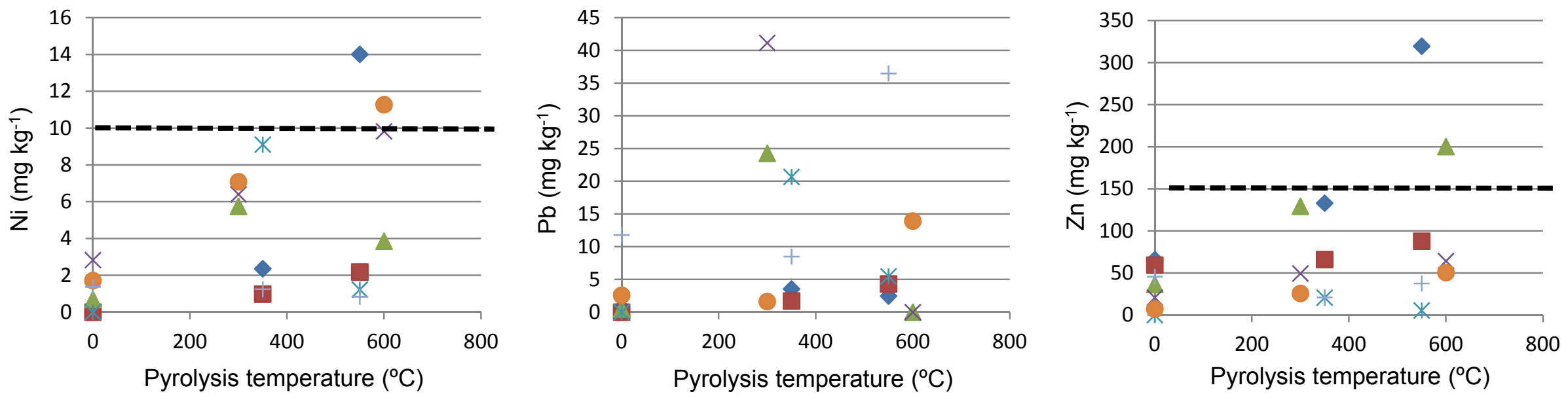

Supplementary Figure S5. Total heavy metal content in the different feedstocks and biochars. Data for unpyrolyzed feedstocks correspond to the pyrolysis temperature of zero $(n=2)$. Mostly obtained from Enders et al. (2012). All the feedstocks and materials were below the heavy metal limit values in IBI (2013), Schmidt et al. (2013), and those for standard grade biochars in Shackley et al. (2013). Dashed lines correspond to the BQM high grade biochar limit in Shackley et al. (2013). 

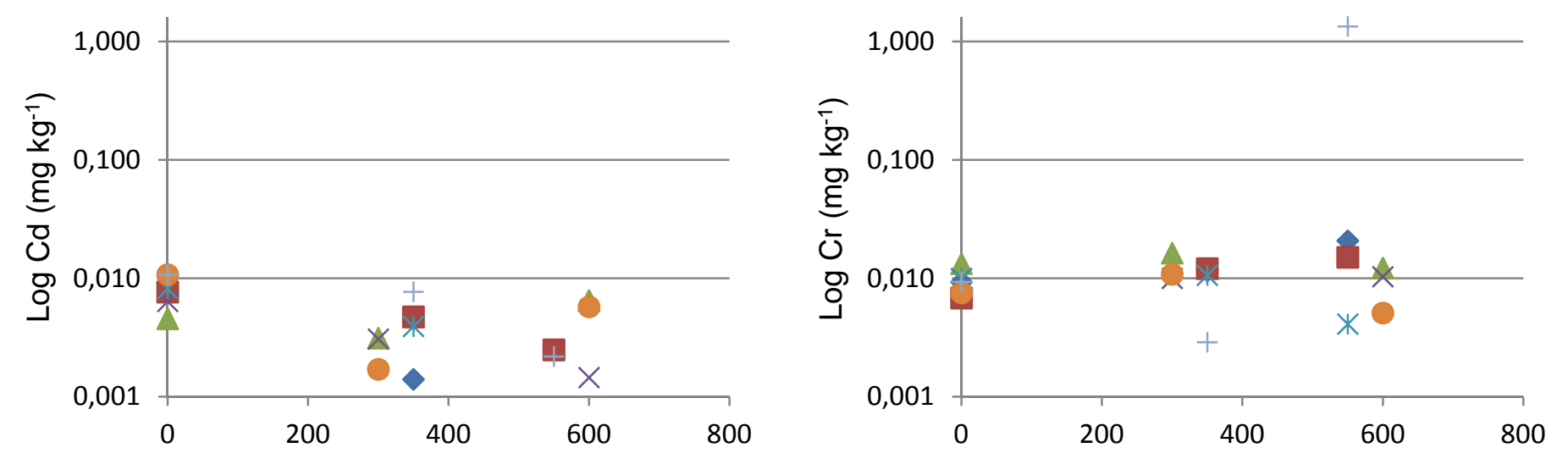

Bull manure

Corn stalks

$\triangle$ Dairy manure

$\times$ Food waste

* Oakwood

- Paper mill waste

+ Pine wood
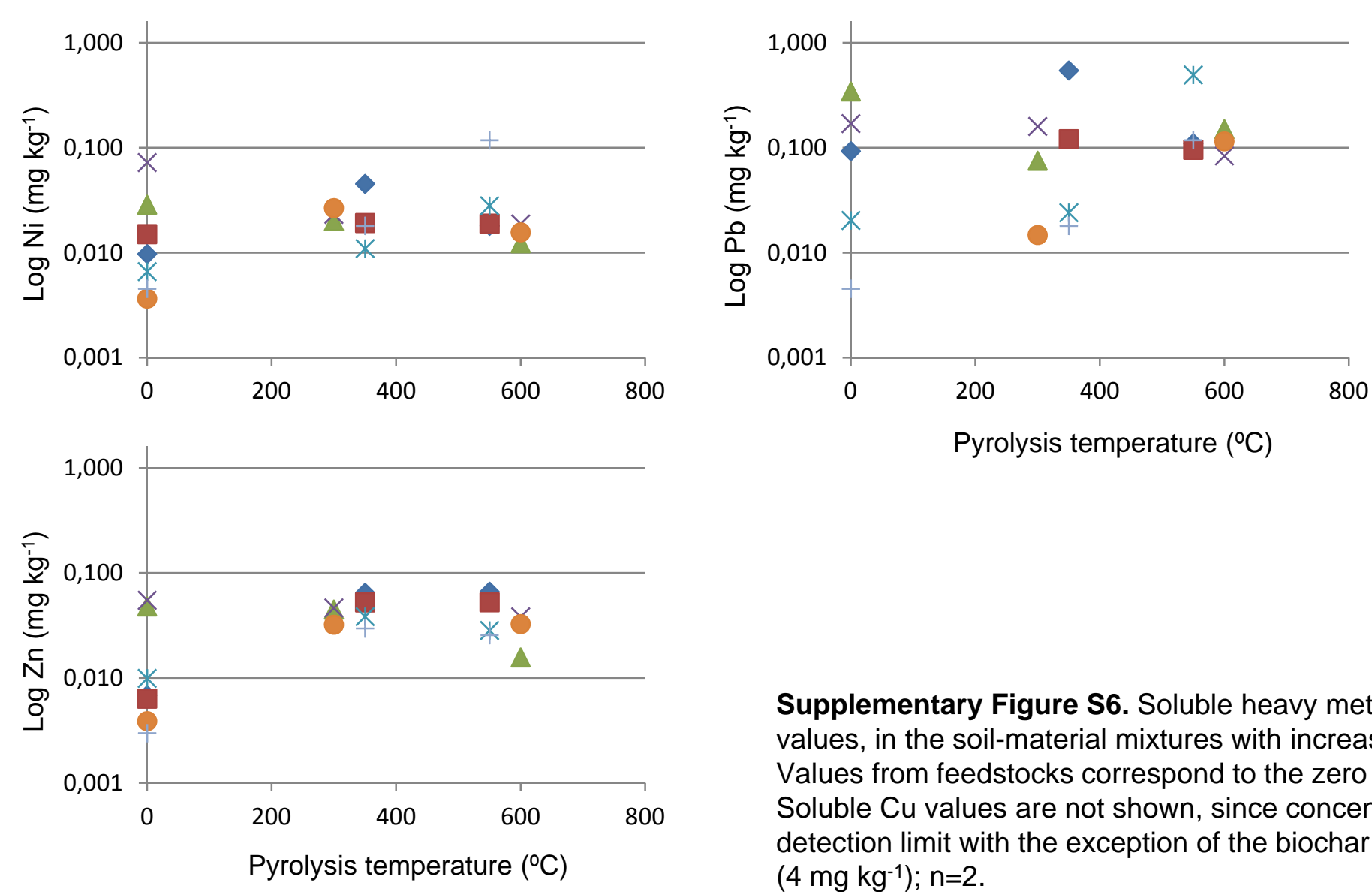

Supplementary Figure S6. Soluble heavy metal content, expressed as logvalues, in the soil-material mixtures with increasing pyrolysis temperature.

Values from feedstocks correspond to the zero value of pyrolysis temperature.

Soluble $\mathrm{Cu}$ values are not shown, since concentrations were below the

detection limit with the exception of the biochar made from pine wood at $550^{\circ} \mathrm{C}$ (4 $\left.\mathrm{mg} \mathrm{kg}^{-1}\right) ; \mathrm{n}=2$. 
Bull manure

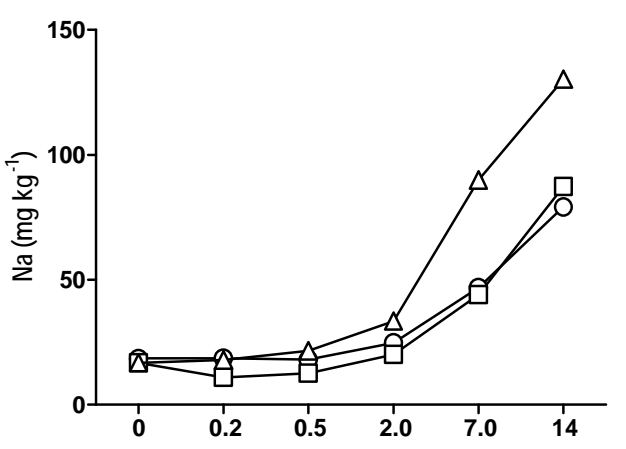

Dairy manure

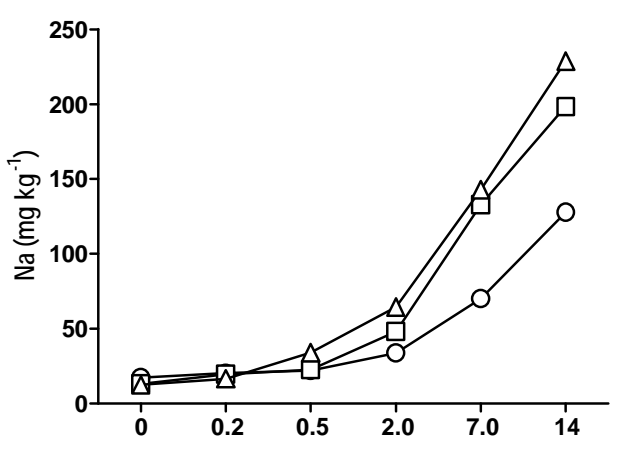

Oak wood

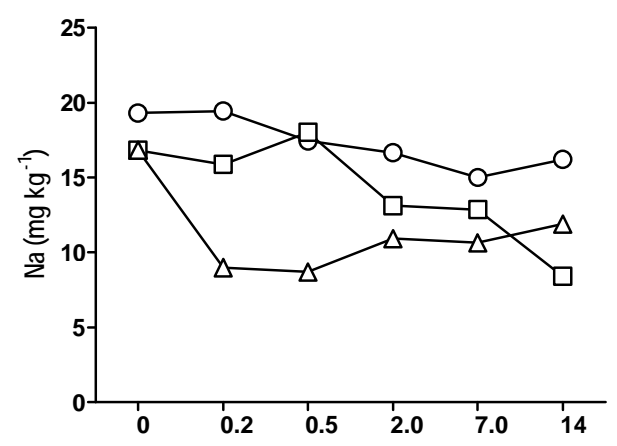

Pine wood

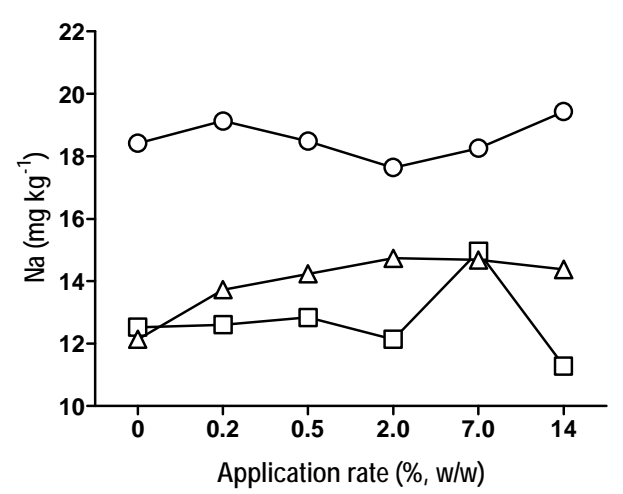

Corn stalks
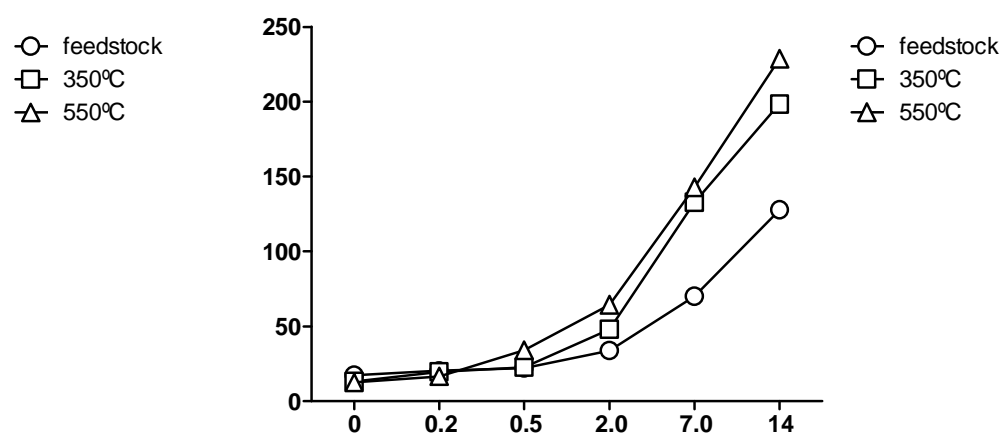

Food waste

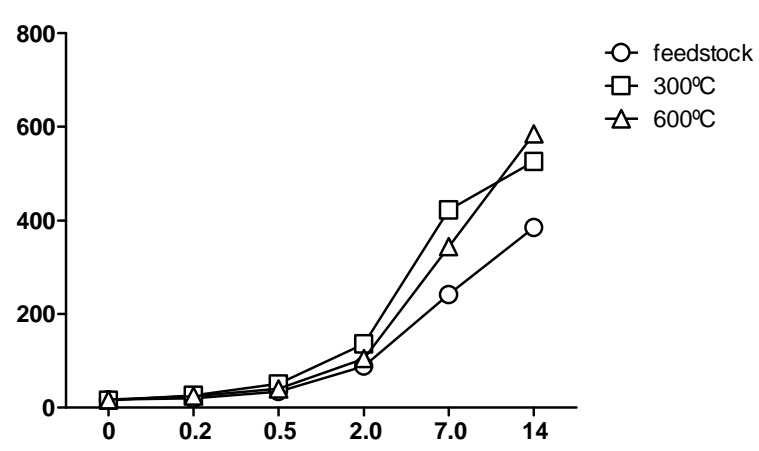

Paper mill waste

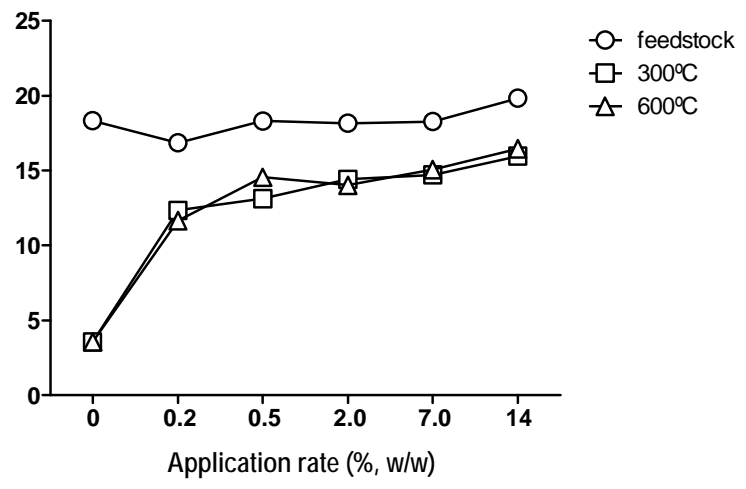

Supplementary Figure S7. Soluble $\mathrm{Na}$ in the different soil-material mixtures at increasing application rates; $n=2$.

feedstock

ㅁ $350^{\circ} \mathrm{C}$

$\triangle 550^{\circ} \mathrm{C}$

-O- feedstock

- $350^{\circ} \mathrm{C}$

$\triangle 550^{\circ} \mathrm{C}$ 